\title{
THE EUROPEAN COMMUNITY \\ AND THE THIRD WORLD
}

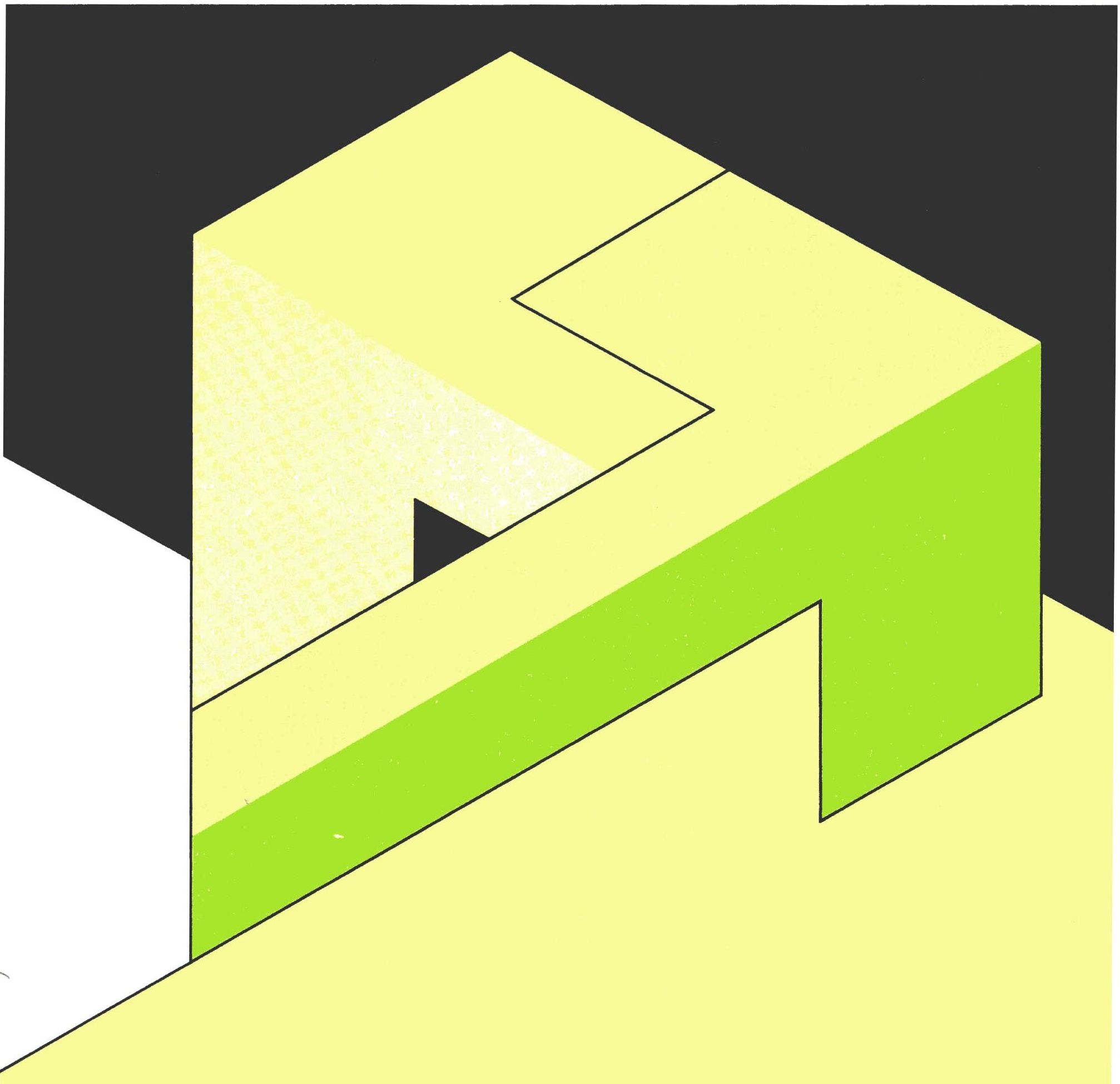


THE EUROPEAN COMMUNITY AND THE THIRD WORLD 


\section{THE EUROPEAN COMMUNITY AND THE THIRD WORLD}

THE THIRD WORLD 6

THE EMERGENCE OF THE THIRD WORLD 6 THE THIRD WORLD TODAY

THE THIRD WORLD'S DEMANDS

THE EUROPEAN STANDPOINT

A TWO-PRONGED POLICY 16

THE REASONS UNDERLYING THE EUROPEAN ATTITUDE 18

THE IMPLICATIONS FOR EUROPE OF A GLOBAL POLICY 23

WHAT THE EUROPEAN COMMUNITY IS DOING 25

ACTION AT THE WORLD LEVEL 25

Commercial agreements with Asian and

$\begin{array}{ll}\text { Latin American countries } & 25 \\ \text { Generalized preferences } & 25\end{array}$

First round of financial and technical help

for non-associated countries 25

$\begin{array}{ll}\text { Food aid } & 27\end{array}$

Emergency financial aid 28

ACTION AT REGIONAL LEVEL

The Mediterranean countries $\quad 29$

The Lomé Convention $\quad 34$

ANNEXES

EEC - Third World relations 39

The European Community 43 
1 The phrase of Pierre Moussa, former Director-General of the World Bank, now Vice-President of the Banque de Paris et des Pays-Bas.

2 The exports of the Community to the Third World are now over more than 50\% more than the total of those going to North America and Eastern Europe lincluding the Soviet Union). 
To cast light on the reasons for the commitment of Europe to the Third World and the nature of this commitment, this booklet puts the two partners side by side:

The European Community, born of centuries of clashes, of conflicts, of wars between peoples, and now trying to come together constructively. After so much suffering and bloodshed in fratricidal struggles, Europeans have come to understand one thing: that they can only preserve the identity of each of their peoples and cultures, and exploit their natural resources and many talents for invention and organization if they act together as a real community, each time it seems necessary to do so, each time the national dimension seems too small. So, through interminable disputes over procedure, with sudden advances followed and accompanied by setbacks, a new entity unprecedented in history has developed-the Community, the European Union of tomorrow. The ambition is vast, the doubts no less so: but the advance is continuing.

The Third World, now emerged from its colonial chrysalis, diverse, immense, rich in abundant natural and human potential, poor in technological development and economically backward. Its peoples want to make themselves heard; they are no longer ready to remain in the margin of history, and have decided to use their capacities, to group theirenergies, to merge theirwills. Time is short, for more than half of them -athousand million human beings-are condemned to 'absolute misery', to use the expression of the President of the World Bank. The 'proletarian countries' 'want to win the right to be themselves, to take part in the definition and the operation of the world economic order.

Will the next decades see a conflicthere, eitheropen or concealed? Will the industrialized countries understand that the rising aspirations of the poor people of the world, people who have been inarticulate up till now, people who we had tried to blind, that these aspirations will not be suppressed? Do they understand that the deep-seated reasons which have made possible our own civilizations and the establishment of equality and liberty in our own world, now compel us to extend to elsewhere the same reasoning and processes which led to the expansion of the free industrial world in the course of the last century?

For Europeans, these questions are in no way academic. On the contrary, their needs, their deficiencies, oblige them to seek a close cooperation with the Third World, an intimate relationship with the people of the South, who want to develop, and who will do so. For the European Community it is at once a moral duty, a political imperative, and a vital economic necessity. ${ }^{2}$

These simple truths are now beginning to be seen more clearly in Europe. This is evident in each of its Member States, evident from the statements of its leaders, from the visits they receive and that they make outside their countries.

It also seems that each one of our Member States is too small to handle the problems, sometimes completely new, which arise from a world in which the economic order is rapidly changing. And, as if by instinct, Europeans have been coming together on this issue. It is therefore hardly surprising that progress in this field on the Community level has been more rapid than in any other sphere of activity. This is also the subject of this publication.

This policy is the result of profound pressures. We can describe its different aspects at a moment in time, at the end of 1977; but the reader must not forget that it is a policy with its own dynamic, and that it is bound to continue to evolve in the years to come.

Claude Cheysson Commissioner for Development 


\section{THE THIRD WORLD}

The Third World consists of two thousand eight hundred million people, living on $51 \%$ of the earth's surface.

They have, on average, an annual income equivalent to US $\$ 300$, which is less than the average monthly income of the inhabitants of the industrialized countries. But it must be realized that in the poorest countries of all, the average annual income per head does not exceed US $\$ 70$, which is what the average inhabitant of the industrialized countries receives each week

The Third World is also a group of more than 110 developing countries, $75 \%$ of whose exportswhich provide their foreign currency receipts-consist of raw materials that are processed and consumed elsewhere. Half of the developing countries depend on a single commodity for over half their exports.

The Third World comprises the overwhelming majority of the peoples of the earth, and they are living in conditions of chronic poverty and under-nourishment. At the same time, the Third World is the supplier of some of the most commonly-used products in the rich countries: coffee, cocoa, cotton ...

\section{THE EMERGENCE OF THE THIRD WORLD}

In the post war years up to the sixties the world economic order could be described without much difficulty as two blocs plus the "Third World' :

- the Eastern bloc, cut off from the rest of the world by the "iron curtain', and meeting almost all its needs for goods and raw materials from among its own member countries;

- the Western bloc, made up of North America, Western Europe and Japan with the United States as its undisputed leader. The US played a major part in deciding the rules of the economic game. It laid down a system of economic, financial and commercial liberalism and the liberalization of international trade by way of General Agreement on Tariffs and Trade (GATT). The monetary system was determined by the Bretton Woods agreements. The US dominated the International Monetary Fund (IMF) and established the American dollar as predominant currency.

- the Third World, meanwhile, consisted of all underdeveloped, dependent or colonial countries. Their point in common-poverty. The Bandung Conference in 1955 established the concept of the Third World. The countries taking part united around the principles of national independence and non-alignment. 


\section{AVERAGE ANNUAL INCOME PER INHABITANT}

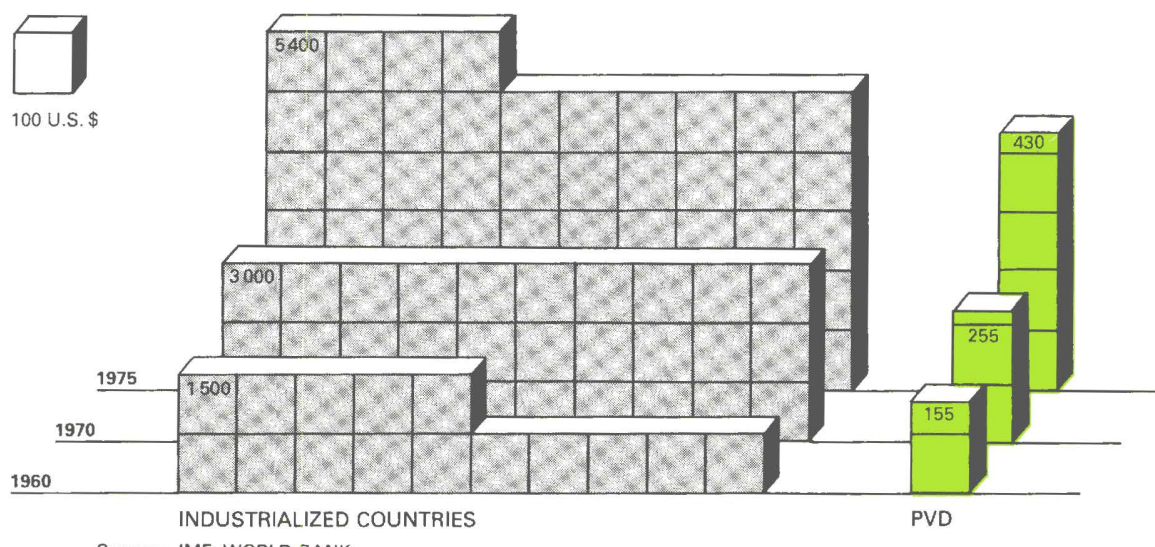

Source: IMF, WORLD BANK. $(20$ to $30 \%$ ) than in industrialized countries (7 to $12 \%$ ). (Source: IMF).

\section{POPULATION}

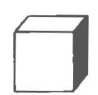

1000000 inhabitants

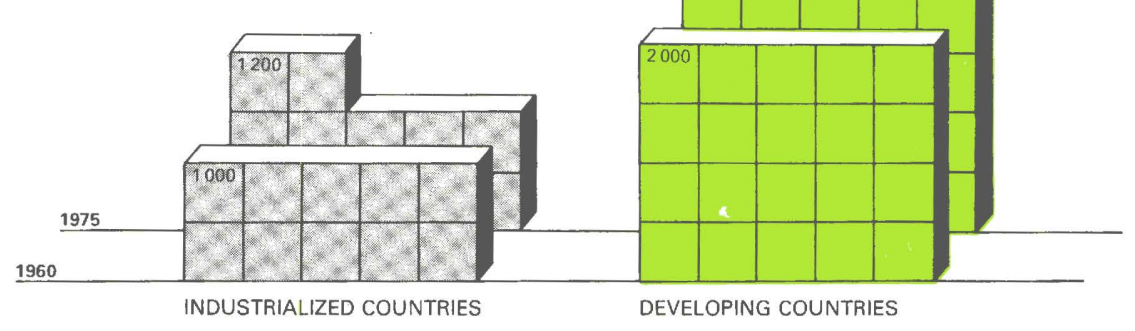

The Third World is, however, subject to the Western economic order, either through the influence of colonization by the Western powers or because it has too little real influence in the bodies where decisions on international relations are taken (United Nations, IMF).

Even during the 1960s, when numerous Third World countries were achieving political independence, particularly those in Africa, the underlying economic relationships between the Third World and the industrialized countries scarcely changed. The drive to independence was essentially a movement for political emancipation.

Seen through the eyes of industrialized countries, the Third World remains what it was during preceding decades : a supplier of raw materials such as mineral ores (iron, bauxite, copper, etc.) and agricultural produce (cotton, coffee, cocoa, etc.).

The Third World's mineral, agricultural and lumber resources continue to be exploited by foreignowned companies. Its reserves have been progressively exhausted, in return for which it has received only modest royalties. Frequently the spin-off in terms of industrialization or training of the work force has been minimal or non-existent.

Conversely, the Third World has to procure a large part of the goods necessary for its survival from the developed countries. The price of machines and equipment, manufactured goods and foodstuffs 


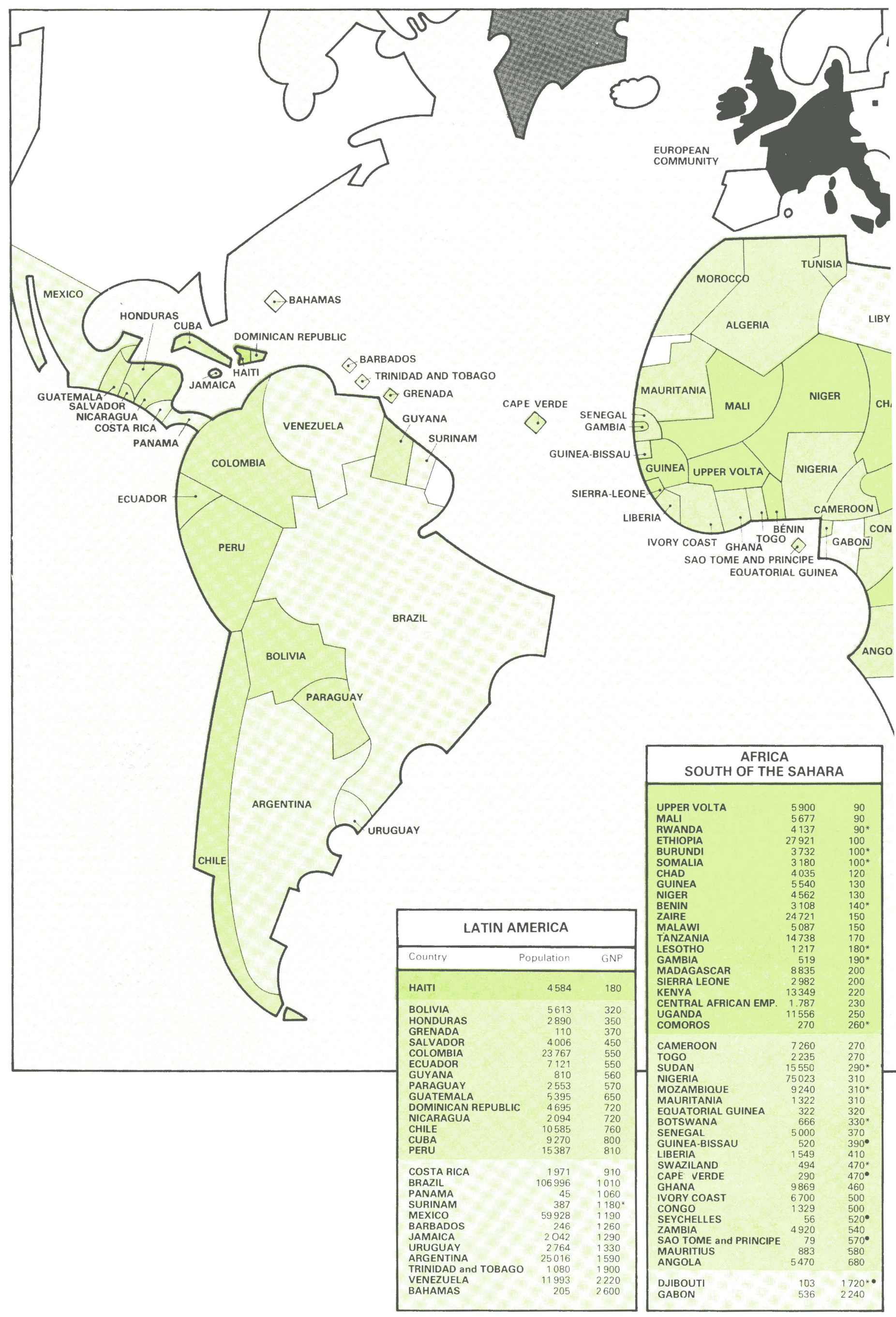




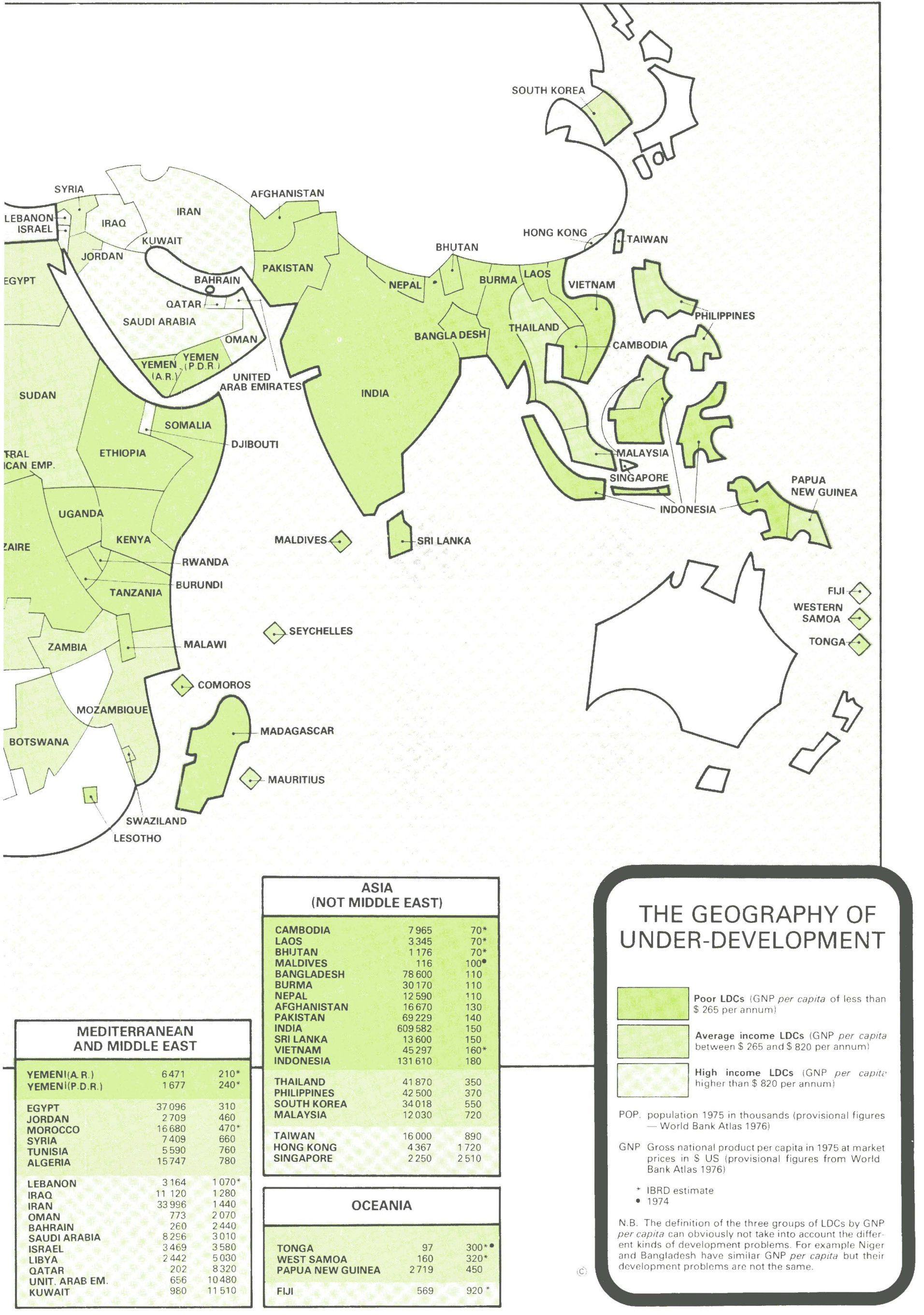


rises more rapidly than the Third World's export revenue. In practice, each developing country has to sell more and more basic products in order to buy the goods it cannot produce itself, which means a continuous deterioration in the terms of trade.

There is thus a growing gap between the rich and poor countries-a situation which has been vigorously denounced by the countries of the Third World.

'A serious attack on the problem of poverty and intolerable disparities of wealth demands a change in the whole direction of world economic activity. Instead of aiming at the maximization of wealth, and the power over others which comes with it, we have to direct our effort towards the creation of reasonable standards of living for all people. This applies to the rich and to the poor-nationally and internationally. Nations which are already wealthy have to accept that they are members of the world, with the right to a fair share of the world's resources but no more. They have to bend their minds, and their economic and political systems, to achieving a fair internal distribution of their existing wealth. They should not expect to continue to deal with problems of comparative poverty within their own nation at the expense of people abroad who are poorer than their poorest. And the poor nations have to face facts too. They need to stop trying to ape the rich. They have to accept that 'closing the gap' does not mean, and cannot mean, attaining for themselves a Western style or level of consumption.'

(Julius Nyerere, speech at the Royal Commonwealth Society, London, November 1975.)

The Western economic order has taken some of the Third World's aspirations into consideration but so far only in terms of financial and technical aid

In 1961 the General Assembly of the UN decided that the period 1960-70 should be the 'development decade' to 'accelerate sustained economic progress' in the developing countries. But the UN did not fix any precise objectives for this undertaking.

Faced with the failure of this first attempt, the UN General Assembly voted in October 1970 for a 'second development decade' with the aim of boosting public aid for development. All the rich countries were expected to give $0.7 \%$ of their gross national product (GNP) (as opposed to $0.44 \%$ in $1964 / 66$ ). The results were feeble: between 1970 and 1974 , the percentage of rich countries' GNP effectively devoted to development aid was between 0.3 and $0.35 \%$.

The concept of public sector aid for development, which has prevailed hitherto, is now widely criticized, and considered by some a failure.

\section{OTHER CAUSES}

OF UNDER-DEVELOPMENT

Economic under-development in the Third World is not only caused by the present economic order but by:

(a) Unfavourable natural conditions such as poor climate lack of natural resources both underground (oil, minerals) and on the ground (forest, fertile soils, surface or underground water)

(b) Human, social and political problems, such as the type of social and political organization favourable to the development process, the continuation of archaic customs and social habits, the low level of agricultural techniques and know-how, the relatively recent establishment of the teaching systems;

(c) Insufficient access to financial and technical means of development-capital, know-how and technologies, access to developed markets. Financial and technical means have been used more to improve natural conditions (infrastructure, agricultural production) rather than to modify essential structures. 
THE CAUSE OF FAILURE

The view of Edwin M. Martin, former Chairman of the

Development Aid Committee of the Organization for Economic Cooperation Development is that the disenchantment of public opinion as to the usefulness of development aid is due for the most part to the illusions people had formed about the world surrounding us, and on the nature of the problem confronting the developing countries. Many people believed, and were perhaps encouraged to believe, that the development problems of the Third World had numerous analogies with that of the reconstruction of Europe, which it was possible to carry out in a very short time thanks to the assistance of the Marshall Plan. In Mr Martin's view this was very clearly a fundamental error. A second problem, in his opinion, is that the attitude of most people has been to give the lessdeveloped countries only as much aid as they could administer scrupulously 'without wasting a penny, inducing bloodshed, or diverting their energies from the one objective of economic development'. In all respects this was the hypothesis that was most lacking in realism. Those who argue this are simply stating what has been man's own evolution. . 'We have known considerable turmoil and -if we take a world historical viewpoint-bloodshed without precedent, even in this very century.' Being restricted from speeding-up the transformation of their societies and their conceptions, the less developed countries feel tensions that are quite evidently greater than ever.

'From our privileged position in the developed countries, many of us consider that we have resolved all our problems and that the developing countries have only to follow our example... We now know that the solutions we applied to our own problems are not generally transferable.' Just as serious, in Mr Martin's opinion, has been the attempt by the developing countries to copy social and political institutions en bloc, without immediately considering the fact that these institutions had been developed over a long period of time in close synchronization with the

development of our economies and our educational system. For having wanted to absorb these institutions too quickly, many countries have had great difficulty in assimilating them.

\section{THE THIRD WORLD TODAY}

The 'oil crisis' in 1973 produced an upheaval in Western thought. For the first time the average European-deprived of his car or faced with petrol rationing-really became conscious of the existence of the Third World.

The developing countries became in the eyes of the rich world an entity to be reckoned with in the international order. They were no longer simply 'needy countries' thought about once a year when the development aid budget was being voted, nor 'suppliers' who were only ever given any thought by trading companies when it suited them. For some, they came to be seen as 'adversaries', for others as potential 'partners' in a differently organized world.

With the Organization of Petroleum Exporting Countries (OPEC) at the international bargaining table, the 1973 'crisis' marked the emergence of the Third World as a collective negotiating power against the rich countries. It also demonstrated, however, just how diverse were the countries which had until then been grouped under one heading: the Third World.

Within the Third World there emerged for the first time countries with rising incomes and others who were not only poor but becoming poorer under the full impact of generalized price increases.

The developing countries fall into three main categories: 
1. THE POOREST COUNTRIES: These have a gross national product (GNP) per head of less than US $\$ 265$ a year. In population terms they total more than a thousand million people who are weighed down by the vagaries of weather and climate and victims to recurrent catastrophes. The problem is simple: survival. India and the Sahel countries are typical of this group, and of the factors that account for underdevelopment :

- A population increasing faster than indigenous food production necessary to sustain it, especially when climatic hazards are taken into account. India alone has a birth rate of around 30 million a year.

- Climatic hazards such as drought (Sahel) and flooding (Bangladesh), are capable of destroying crops and livestock and cannot be effectively combated by men or governments.

- Lack of exploitable natural resources, or inadequate earnings from the few products they export. The trade balance of these countries is usually heavily in the red, even when imports are kept to the bare minimum.

- Environmental deterioration, partly as a result of the climate and partly due to the lack of an adequate agricultural, forestry and stockbreeding policy. In the Sahel, for example, substitution of basic crops by more commercial ones has accelerated soil impoverishment. Absence of fencing for livestock had led to over-use of pasture land and to deforestation-also aggravated by the domestic use of wood for cooking and construction. This environmental deterioration also encourages encroachment by the desert.

- Deterioration in terms of trade. This is in effect a result of the world economic order: prices increase more rapidly for imported manufactured products than for exported basic products and the result is a growing imbalance between imports and exports. Consequently the purchasing power of the poorest countries never ceases to fall. Massive non-repayable financial aid remains the key factor for their survival.

\section{AVERAGE INCOME COUN-} TRIES:

Situated between the two extremes, these countries tend to be more favourably endowed by nature than the poorest, but still fall outside the top group of developing countries. Some have sizeable oil revenues, or other earnings, but have a large population (Algeria). Some possess major resources and are involved in long-term industrialization programmes. Others export basic agricultural produce in an attempt to reap the maximum profit in the shortest possible time, in order to be able to develop the other sectors of their economies (Ivory Coast).

Financial and technical aid, and above all, industrial and technological cooperation continues to be of considerable importance for these countries.

\section{COUNTRIES WITH HIGH} INCOMES:

These are the beneficiaries of the spectacular rise in price of raw materials, and include the majority of the oil exporting countries. They have the means to achieve their ambitions and are motivated by the desire to free themselves once and for all of the constraints they were burdened with until recently.

The sudden wealth of these countries came from exploiting their strong negotiating position, which derives from the fact that the raw materials they possess (oil, minerals, etc.) are vital for the industrialized countries.

They are still dependent on the industrialized countries for their outlets but have embarked on a rapid industrialization programme in order to dispense with importing manufactured goods, and in some cases to become exporters.

In addition to massive investment of their financial surplus in the profitable sectors of the Western economies, these countries have made a big effort to give financial and technical aid to the Third World's most impoverished countries. 
The countries of the Third World make up $75 \%$ of world population but receive only $10 \%$ of world revenue. Their claim for 'more equitable world economic order' covers all sections of their relations with industrialized countries:

\section{RAW MATERIALS :}

- stabilization of export income from raw materials

- maintenance of purchasing power of developing countries which export raw materials (indexation);

- adding to value of raw materials through processing on the spot;

- surveillance of the conditions for competition between natural products and synthetic substitutes.

\section{ENERGY:}

- recognition of the limited character of oil and natural gas resources;

- maintenance of the purchasing power of revenues coming from export of energy;

- development of all forms of energy.

MANUFACTURED PRODUCTS AND INDUSTRIAL

DEVELOPMENT :

- international redistribution of industrial activities to give developing countries a greater share of world industrial production, thus enabling them to satisfy their own domestic needs - encouragement of industrial investment in the developing countries with a transfer of technology:

- access for manufactured products from developing countries to the markets of industrialized countries: elimination of tariff and non-tariff barriers.

SERVICES AND THE TERTIARY SECTOR:

- greater participation by developing countries in the field of maritime transport, insurance, tourism, etc. :

- reduction in the cost of access to technology: patents,

know-how, etc.

\section{AGRICULTURE AND FOOD}

- development and

diversification of the production of developing countries to meet their general food needs:

- increase of financial resources devoted to agricultural development;

- improvement of food aid programmes.
PUBLIC AID AND PRIVATE CAPITAL TRANSFERS

- the public aid objective for the second development decade

$10.7 \%$ from the rich countries) to be met and the conditions attached to it made less strict: - increase of resources from international development finances - World Bank

International Development Association (IDA), 'regional banks';

- increase of access to resources (notably from IMF) to cover balance-of-payments difficulties;

- cancellation of public debt of developing countries;

- rescheduling by new methods of public debt of developing countries;

- measures to protect developing countries from inflation.

INTERNATIONAL DECISIONS:

- increased role of developing countries in international institutions (notably IMF where they have $50 \%$ of seats and $27 \%$ voting rights);

- right of participation in common administration of common resources (for example, submarine resources)

- code of conduct for multinationals

- respect of the right to collective organization by developing countries which export raw materials, and of their sovereignty in fixing prices. 


\section{THE PLACE OF INDUSTRIAL COUNTRIES (WESTERN AND SOCIALIST) IN THE WORLD ECONOMY - 1970-1974}
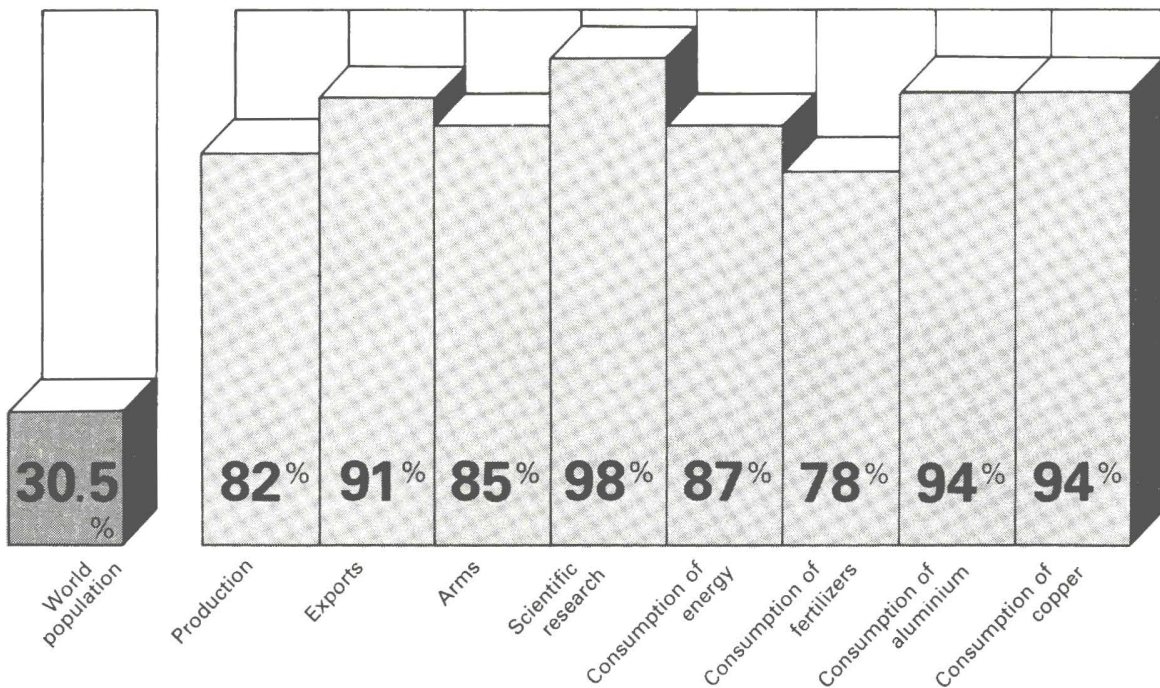

finance... Representatives of the Third World have stressed that from now on their stance is a united one, based on the principle of equality in relations between States. This unity is demonstrated in the way they work together in the 'Group of 77' (which has in fact far more than 77 members).

Certain observers in the industrialized countries take the view that the 'oil crisis', and now the Third World's global objectives, represent a merciless desire for confrontation with the industrialized world. This is denied by the developing countries.
Shridath S. Ramphal, Commonwealth General Secretary, stated in September 1975:

'When the developed countries complain at seeing the price of oil unilaterally increased, it should be recalled that the price of manufactured products (sold to the Third World) are purely and simply fixed on the invoice it receives.

Let us avoid using the label of conwhich is only an attempt by the developing countries to make negotiation procedures more equitable.' frontation to describe something
These wide-ranging but precise claims of the Third World (see page 13) confront the rich world, especially the European Community, in all international meetings and circles.

This is not to say that they have to accept such claims, or should try to reply to them alone, nor that these demands are the best way of obtaining a new world economic order The only certainty is that the old order is no longer viable, and that faced with the new demands of the Third World, immobility is unrealistic. 


\section{THE EUROPEAN STANDPOINT}

Europe of the Nine, the European Community, was not made in a day. It is the product of progressive reconstruction. As the developing countries progress, and progress is also made in the construction of a united Europe, ${ }^{1}$ European attitudes towards the Third World should change for the better.

Also, it must be underlined that the Community does not yet present one face to the developing countries. The national policies of Member States coexist with Community policy as decided by the Council and administered by the Commission. The role of the Community is thus both a harmonization of national policies and an implementation of a specifically Community policy, to the extent that responsibilities in the development field have been granted to it by the Member States.

Thus in the trade field, where the Community has exclusive responsibility, developing countries deal only with the Community, and not with any one of the nine Member States.

In the area of financial aid ${ }^{2}$ the specifically Community policies complement the bilateral policies of the Member States and their multilateral contributions outside the Community (World Bank, UNDP, IFAD ... . . ${ }^{3}$

Elsewhere, in international negotiations with developing countries the responsibilities of the Com- munity vary case by case: it can speak entirely for the Nine as at the North-South Dialogue, or act as 'coordinator' of the Nine, or be represented as an observer.

\footnotetext{
See page 16 'Important dates of the Community' and the annexes, page 39 the history of the Community's development policy.

2 See table on page 21.

3 See page 38.
} 
IMPORTANT DATES

IN THE HISTORY OF THE EUROPEAN

COMMUNITY

AND ITS RELATIONS WITH DEVELOPING

COUNTRIES
Signing of the Treaties of Rome setting up the European Economic Community (EEC) and Euratom which came into operation on 1.1.1958. The six countries signing it decided that the overseas countries then attached to them should be associated with the development of the Community. They benefit notably from the European Development Fund (EDF).

Signing at Yaounde of the first Association Convention between the EEC and 18 African States and Madagascar (AASM).

The first food-aid programme of the Community (cereals) begins operation.

Signing at Yaounde of the second Association Convention between the EEC and the 18 AASM for a period of five years.

Signature of the Arusha Convention between the EEC and the three countries of the East African Community (Kenya, Uganda, Tanzania).

Entry into force of the Community's generalized preferences scheme.

The Commission presents to the Council of Ministers a 'Memorandum on a Community

Policy for Cooperation and Development'. Denmark, Ireland and the United Kingdom join the European Community. Protocol 22 makes special provision for developing Commonwealth countries.

Accession of Mauritius to Yaoundé II Convention bringing the number of AASM to 19.

Paris Summit, Community leaders call for a global cooperation and development policy' for the Community.

Start of negotiations between the EEC and the ACP countries in Brussels.

Memorandum of the Commission for a global food aid policy.

EEC Commission proposal to set up US $\$ 3000$ million emergency fund for developing countries worst hit by price rises in vital products.

First session of Euro-Arab Dialogue.

Publication by the Commission of the document 'Development aid: Fresco of Community action tomorrow'

Signing of Lomé Convention between the nine EEC members and the 46 ACP States.

Entry into force of the EEC-Israel Agreement

EEC-ACP Lomé Convention comes into force. Signature of Agreements EEC-Tunisia (Tunis 25.4.1976) EEC-Algeria (Algiers, 26.4.1976)

EEC-Morocco (Rabat, 27.4.1976).

First meeting in Brussels of the EEC-ACP joint Council of Ministers.

First financing of projects in Asia: India,

Bangladesh, Indonesia.

Signature in Brussels of EEC Agreements with Egypt, Jordan and Syria.

Signature in Brussels of a financial protocol complementing the EEC-Israel Agreement of 1975.

Signature in Brussels of the EEC-Lebanon Agreement.

In the framework of the North-South Dialogue, a special action programme for the least-favoured developing countries, of US $\$ 1000$ million is adopted. The EEC agrees to contribute US $\$ 385$ million.

\section{A TWO-PRONGED POLICY}

The Community's Third World policy combines two approaches: special contractual agreements on a regional basis; action at world level.

The Community has concluded a wide range of regional agreements :

(1) The Lomé Convention, which sets up special relations between the European Community and $\mathbf{5 2}$ African, Caribbean and Pacific (ACP) countries. A small number of countries in a similar position have been or will be included, so the ACP countries form a homogeneous group;

(2) The agreements with the Maghreb countries (Algeria, Morocco and Tunisia) and with three Mashreq countries; Egypt, Jordan, Syria, and with Lebanon. Also the agreement with Israel.

This kind of regional deal has some completely original aspects :

(1) the agreements combine all types of financial, technical and commercial action to bring about change in the structure of their economies;

(2) the beneficiary countries decide themselves to what end this action is to be undertaken;

(3) these agreements are written into international treaties ratified by the parliaments. They thus make up a juridical obligation for Europe. 
The amounts cited in the text are put in units of account (u.a.) or in European units of account (EUA)

The value of the $u$.a. is based on gold and corresponds to US $\$ 1.20635$, FF 5.55 or FB 50.

The value of the EUA, used for the EDF is determined each day in relation to a basket of Community currencies and thus varies with the different exchange rates. On 5 September 1977, the EUA was worth US $\$ 1.14$, FF 5.60 , or FB 40.72

\section{CHART OF THE COMMUNITY'S COOPERATION POLICIES WITH THE THIRD WORLD}

\begin{tabular}{lll}
\hline Sector & Commercial policy & Financial and technical cooperation \\
\hline Responsibilities & $\begin{array}{l}\text { Executive responsibility } \\
\text { of the Community }\end{array}$ & $\begin{array}{l}\text { Joint responsibility } \\
\text { with Member States }\end{array}$ \\
\hline
\end{tabular}

$\begin{array}{ll}\begin{array}{l}\text { Regional } \\ \text { agreements }\end{array} & \text { Commercial aspects of the } \\ & \text { EEC-ACP Lomé convention } \\ \text { (free access) }\end{array}$

Commercial aspects of the Maghreb, Mashreq and Israel agreements (free access in most cases)

Global Generalized preferences level

\section{(Community scheme)}

Commercial agreements of different kinds with developing countries

Export promotion for developing countries
Financial aspects of the

Lomé Convention (1976-80):

EDF $=3054$ million EUA

$\mathrm{EIB}=390$ million EUA

Financial aspects of Maghreb, Mashreq, Israel (to 31.10.1981) Agreements:

$E E C=307$ million $\mathrm{u}$.a. (7 countries)

EIB $=362$ million u.a. (8 countries)

Food aid:

cereals: 1286 million u.a. (1968-77)

other : 653 million u.a. (1968-77)

Emergency funds:

EEC : 292 million u.a. (1974-75)

Member States: 430 million u.a. (1974-75)

Financial cooperation with other developing countries:

EEC: 20 million u.a. (1976)

EEC : 45 million u.a. (1977)

Export promotion and regional cooperation:

EEC: 3.5 million u.a. (1976)

EEC : 5.4 million u.a. (1977)

Cofinancing with non-governmental organizations:

EEC: 2.5 million u.a. (1976)

EEC : 4.0 million u.a. (1977) 
The continuity of relations is therefore guaranteed, whatever the political orientation of the beneficiary countries; these can thus plan in advance their cooperation with Europe. ${ }^{1}$

Action undertaken at world level, consists of :

- various sorts of commercial agreements with Mediterranean, Asian and Latin American countries;

- the Community's system of generalized tariff preferences;

- financial and technical aid to non-associated countries;

- food aid.

- specific action such as the establishment of an 'emergency fund' - non-governmental organizations.

There is thus both cooperation involving a large number of the developing countries without discrimination (generalized preferences, food aid); and specific cooperation tailored to each country's requirements (country by country commercial agreements).

Thus the Community's policy towards the Third World is a combination of regional agreements and action undertaken at the world level. This corresponds both to the guidelines set out by the Treaty of Rome, which instituted a special relationship with countries which were either near to the Community geographically or linked to it historically, and the current trend in the pattern of economic relations, which means that the Community cannot exclude any potential partner.

Two things need to be said about this policy:

- the Community has set clear geographical limits to its policy of treaty-based regional cooperation, which covers the African, Caribbean and Pacific States, plus the Maghreb and the Mashreq countries;

- a policy built on a double axis (regional agreements and worldlevel action) is an answer to the fears sometimes expressed that Europe is helping to divide the world into zones of influence. For example, the Community, when negotiating the Lomé Convention, dropped the principle of reciprocal tariff concessions which would have forced its trading partners to give it preference over other industrialized countries.

\footnotetext{
1 The Lomé Convention lasts five years, but the 'Sugar Protocol' is of unlimited duration. The Maghreb and Mashreq agreements have unlimited duration, except the five-year financial protocols.
}

\section{THE REASONS UNDERLYING THE EUROPEAN ATTITUDE}

For a long time people seriously asked whether it was necessary to help the Third World. More often than not the reply given was fuzzy. Development aid from public funds-for long regarded as an act of charity or at best solidarity -was merely something that each government had to justify and defend once a year when its budget was voted.

The 'oil crisis', and the international economic upheaval that accompanied it, brought out certain basic facts about the relationship between the Third World and industrialized countries. As a result, the key word in cooperation policy with the developing countries is now interdependence.

The industrialized countries, and especially the European Community, depend on the developing countries for two main reasons:

- most of the raw materials (oil, phosphate, iron, bauxite, etc.) and commodities (coffee, cocoa, citrus fruit, textile fibres, etc.) used by their industries come from the developing countries. Reliable and guaranteed supplies are indispensable, failing which they would suffer serious shortages and the threat of crises;

- the Third World is becoming an increasingly important market for their industrial products (factories, machine-tools, railways, vehicles, etc.) helping to keep European industry fully employed. 


\section{EEC AND THE THIRD WORLD}

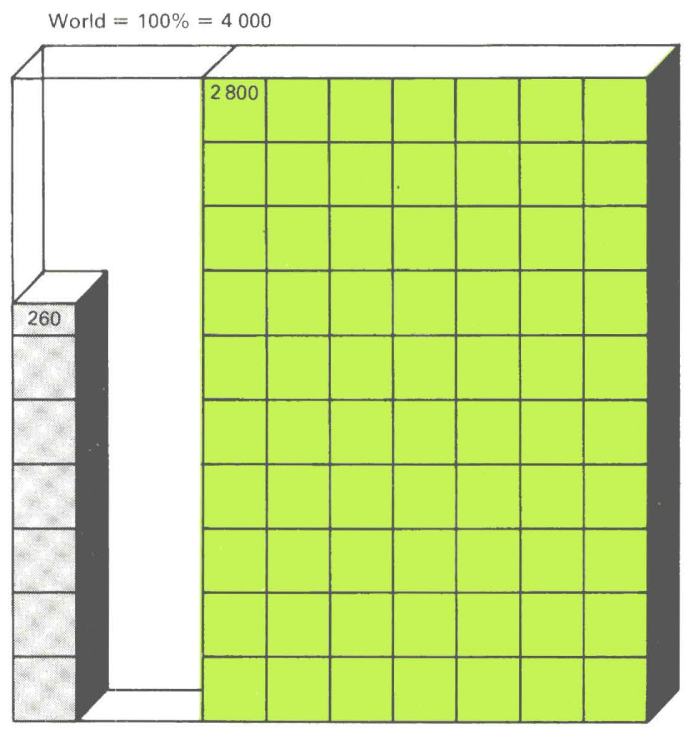

POPULATION 1975

(in millions of inhabitants)

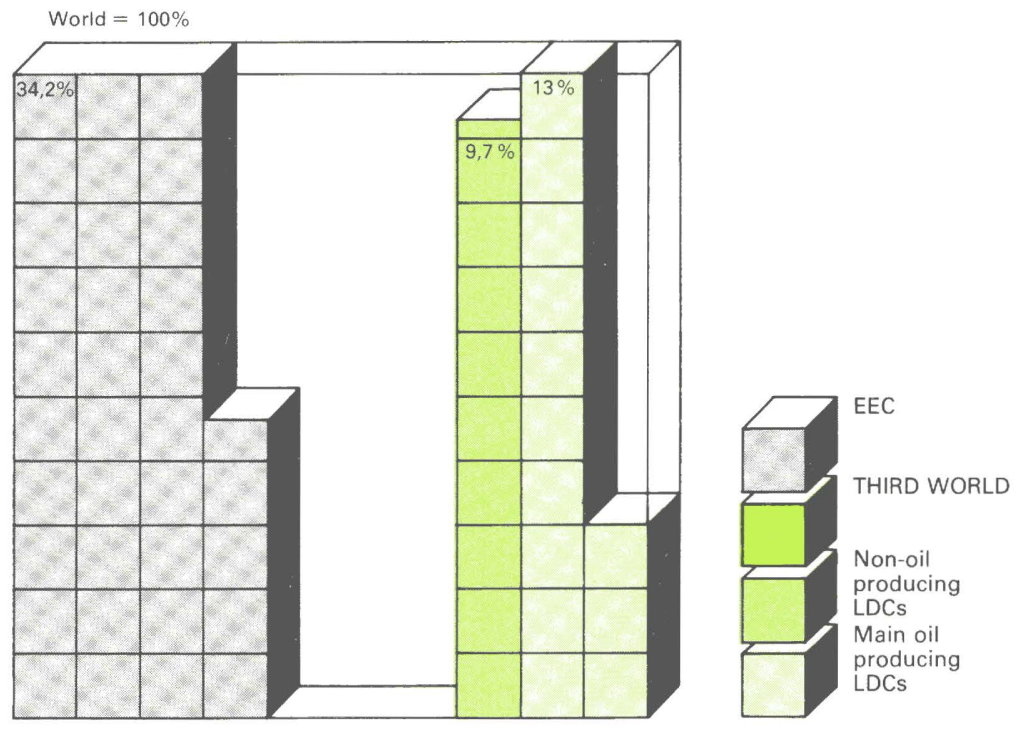

EXPORTS 1975

(in \% of world exports)
The developing countries need the industrialized countries in order to be able to launch and sustain their development. In particular: - the developing countries' commodities are still mostly im ported by industrialized countries in their processed form and these export earnings are vital for exporters in the developing countries;

- the most advanced developing countries are embarking on intensive industrialization, and at present the indispensable technology and know-how belongs to the industrialized countries;

- the majority of developing countries, whether poor or advanced, require an increasing volume of capital, in a form they can use. For this they have to depend, for the most part, on developed countries.

The European Community in fact supplies close on $50 \%$ of the public aid distributed by members of the OECD Development Assistance Committee (see table).
But two points must be stressed: - some developing countries have become considerably richer following the rise in the prices of raw materials which they have imposed on the industrialized countries. The latter have been seriously weakened as a consequence. Financial aid might no longer be necessary on the one side - or even possible on the other.

- in the face of producer 'cartels', intimidation and unilateral decisions, the industrialized countries 
might prefer to take a tough line rather than try to build up nonreciprocal cooperation.

Some of the developing countries, but by no means all of them, have virtually become rich, in economic terms. But neither the Sahel countries, India or Pakistan gained any benefit from the 'oil crisis': nor were they protected from its impact.

The need for financial aid is still enormous. One thousand million people in the Third World live in economic conditions that do not permit them to develop. When population growth is taken into account, their real resources are actually decreasing. Increased financial aid is imperative and should be gi-. ven on a world-wide basis, mobilizing all available resources, including those of developing countries with large financial surpluses.

On the other hand, could Europe face a confrontation with the Third World?

'Our European countries have always had to look overseas for markets and supplies. It used to be spices. Now they need raw materials and basic products. This can be summarized with a few figures: the Europe of the Nine accounts for $25 \%$ of world trade lexcluding inter-Community trade) as against $14 \%$ for the United States and 4\% for the USSR. Maintaining this trade and smoothly adjusting it with time are preconditions for Europe's survival. If the major continental coun- tries decided on confrontationwhich might not disturb their own economies too much-and caused an iron curtain to fall between the North and the South, 'we know that our economies would not be able to withstand it.' (Claude Cheysson)

Indisputably, new elements are emerging in the world economic and political order, as concerns both the major powers and the developing countries. Thanks to the recent economic upheaval, and the major international discussions that followed it, the developing countries now have a chance of becoming partners in the world economy as opposed to being mere suppliers for the industrialized world's growth. Vast changes are predictable at the world level in the industrial, financial and commercial structure of relations between the developed North and the developing South. Against this rapidly-changing background, the Community, through its cooperation policy, seeks to keep abreast of events.

The Community's global policy for cooperation with the Third World, taking account of the growing interdependence between North and South, needs greater financial resources. But financial aid by itself is only one aspect of the problem. Cooperation policy also involves a series of measures aimed at ensuring an increased income for the developing countries from their own resources. These countries must be able to guarantee their export earnings against violent fluctuations. They must be equipped for on-thespot processing of an increasing proportion of basic products to increase their export value. They need to have the best possible access to the industrialized world's markets to acquire industrial technology and know-how easily and cheaply. So a global policy for cooperation with the Third World has also to consider the consequences of these moves for the European economies.

\footnotetext{
It would be more exact to say between the South and the West, because 'the bloc of socialist countries is absent from the field of cooperation: its development aid is minimal, its share in the trade of the. Third World is $5 \%$ as against $20 \%$ for the USA and $40 \%$ for the EEC. However, certain problems can only be resolved with their participation. notably problems of raw materials. They must therefore be brought into the dialogue'. (Claude Cheysson)
} 
OFFICIAL DEVELOPMENT ASSISTANCE OF MEMBER STATES OF THE COMMUNITY (NET DISBURSEMENTS 1976)

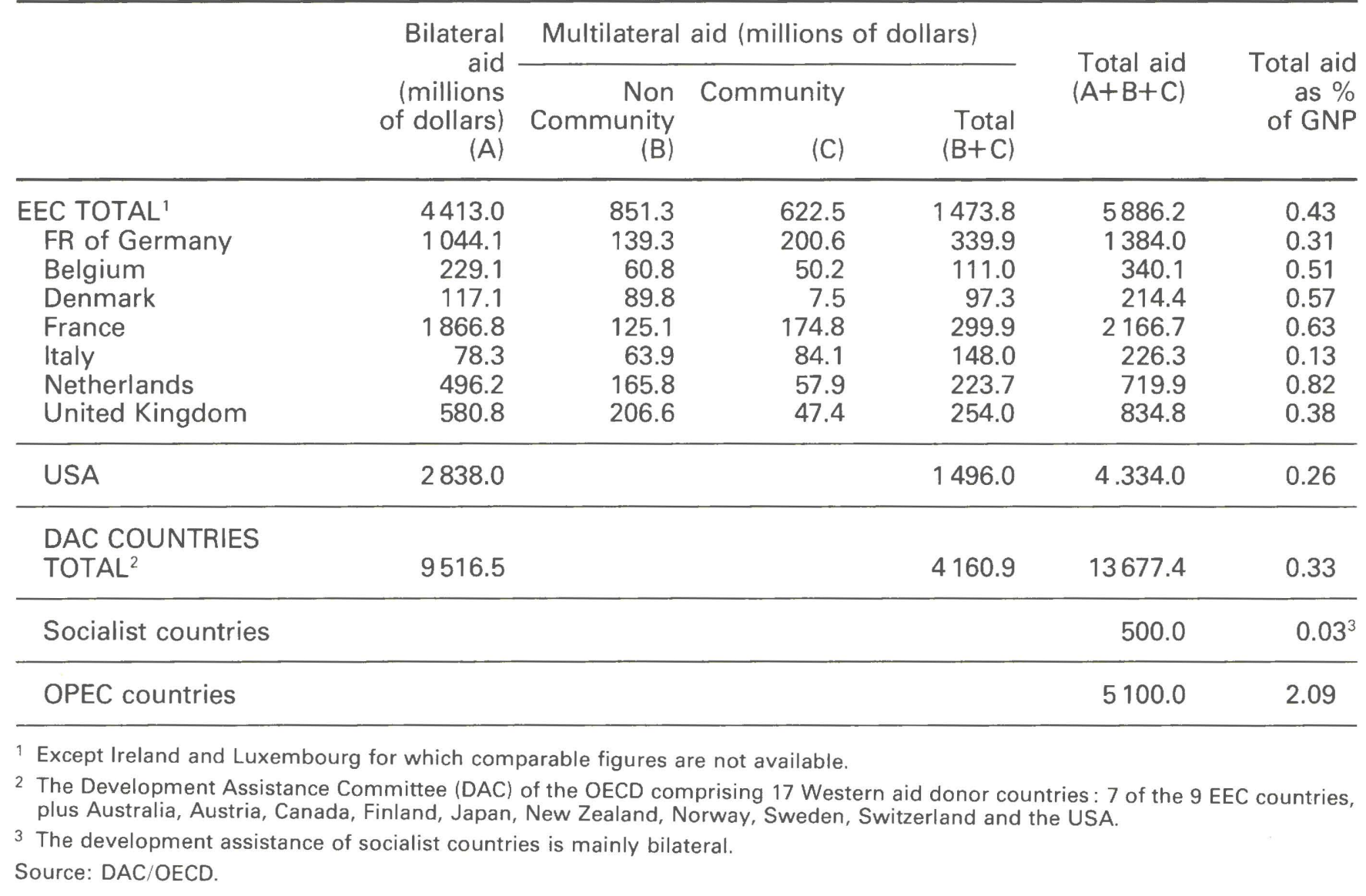




\section{NORTH-SOUTH INTERDEPENDENCE}

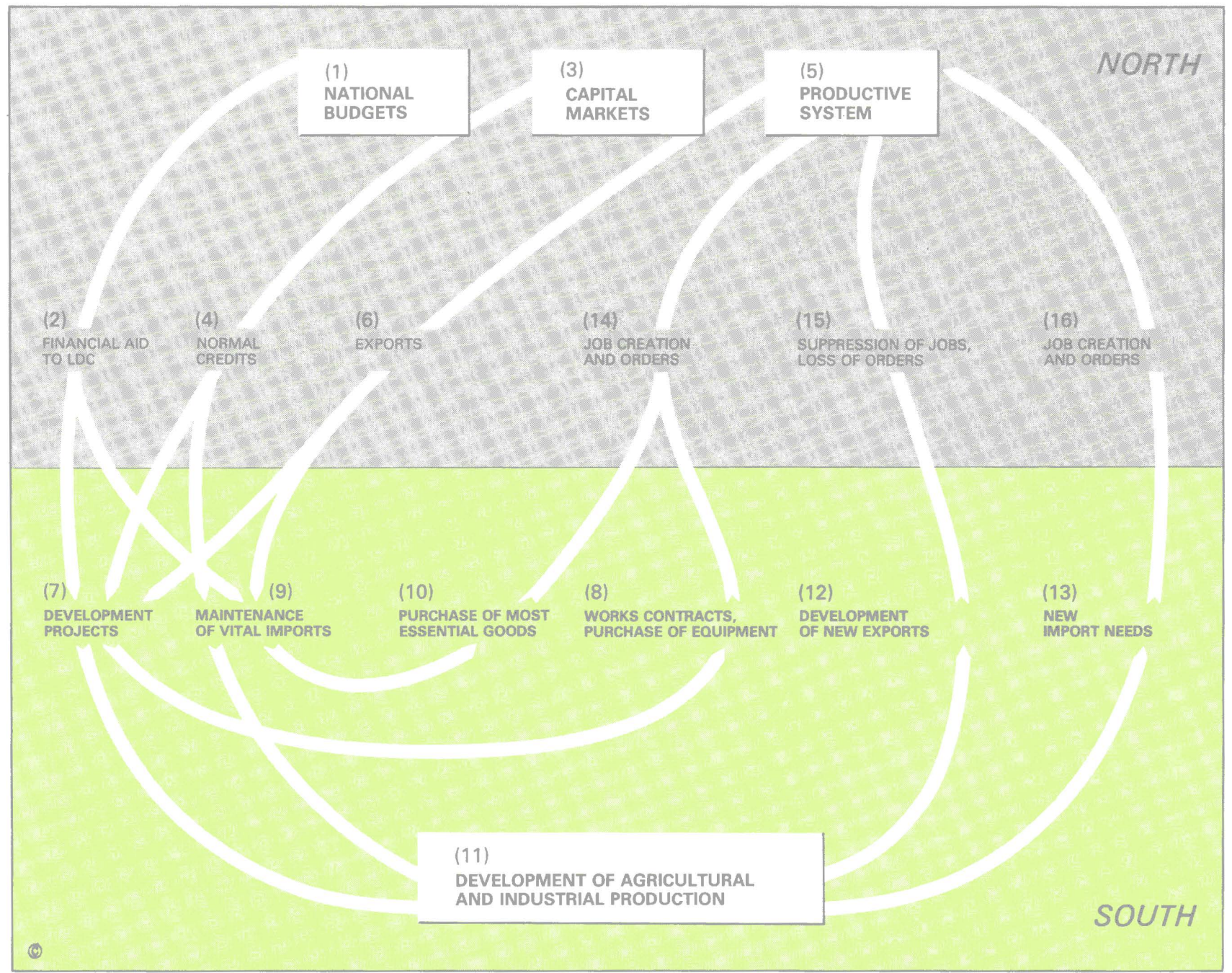


The national budgets of industrialized countries (1) furnish aid to developing countries (2) while capital markets (notably private banks) (3) furnish normal credits to LDCs (4). These financial flows from North to South permit the financing of development projects (7): roads, plantations, factories, etc. or to maintain imports vital to the LDCs' economic life: foodstuffs, fertilizers, fuel (9).

These financial flows are immediately used by the LDCs to buy essential goods (fertilizers) in industrialized countries (10) to grant works contracts (roads, factories) and to buy equipment (8).

These in turn are converted in industrialized countries into new orders and jobs (14) in the productive system (agriculture, industry, services) (5) which develops exports (6) At the same time, in the LDCs, the productive system continues to operate thanks to the

maintenance of the capacity to import vital goods (9) and to develop thanks to projects (7) Hence increased agricultural and industrial production (11)

This new industrial production (textiles, clothes, shoes, radios, electronic products) are exported (12) to industrialized countries who find a new competition for their own producers (5) leading to loss of order and suppression of jobs (15).

However, the process has its own dynamism, and the development of LDCs industrial production (11) can generate orders of a new type (13) ' Key' factories, replacement of machines, spare parts, which become new orders and jobs for the "North'(16). Such is the new interdependence between North and South.

Thus, thanks to the opportunities for the LDCs to borrow on the capital markets at the price of a heavy indebtedness for some of them, the industrialized countries can maintain their sales to the LDCs, and thus their employment levels, at a time when trade within the industrialized world is slowing down due to recession.

The overall problem is one of ordered functioning and control of these mechanisms of

interdependence. If the new exports of the LDCs (12) develop an anarchic fashion, the productive system of the industrialized countries will be disorganized (15). If the transformation of North-South relations could take place in an ordered way, the LDCs could obtain their rightful place in the world economy and improve the conditions of their people. At the same time, the industrialized countries at the cost of certain adjustments in their structures of production (for example in producing fewer cotton shirts but more elaborate garments, fewer portable radios and more computers) could vitalize their economies and thus maintain and develop employment levels and the standard of living of these populations.

\section{THE IMPLICATIONS FOR EUROPE OF A GLOBAL POLICY}

Cooperation policy should be recognized as being of marginal importance as long as it consists only of financial aid. Once it includes guaranteed export earnings (Stabex system), guaranteed selling at fixed prices (ACP sugar cane agreement), action for industrial redeployment, access to European technology for the developing countries, (EEC/ACP industrial cooperation), and movement of workers (agreements with Maghreb countries), the very notion of international division of labour is called in question. For it then directly affects the Community's economy and Community industries and workers.

The impact on the European economy is both industrial and agricultural. So both employment and wages are effected. For instance: - When the European Community introduces a system of generalized tariff preferences (lowering of customs duties on imported processed products) and prepares, as it is now doing, to finance access for the Third World to industrial technology and facilitate the transfer of industry, it does so to help the industrial development of the Third World. As a result, the Mediterranean countries, and later the ACP countries, could rapidly begin competing industrially with the Community.

- The Community is acting in a similar way in the agricultural 
sector: it is opening its markets to agricultural produce from the Mediterranean and Africa, and financing production schemes. Such direct competition worries producers in the south of the Community. So the Community is taking a risk when it pursues such farreaching cooperation with the southern Mediterranean countries and ACP countries: it is counting on the fact that the two areas-Community and developing countries - need each other, outweighing the obvious competitive threat.

'Let's dwell for an instant on agriculture, since farmers in Italy and the Midi regions of France rightly dread the import of certain products from the Maghreb, and maintain that their claims ought to be treated openly. Let us look at the considerable market for food and agricultural produce which the Euro-Arab world offers, and the impressive volume of these products imported from countries outside our common zone. We shall see with astonishment, and then with hope, that a large number of these products could be developed at home on both sides of the Mediterranean. Then we shall realize that if we deal with ourproblems jointly, the scope for development is immense, even in the areas that appear to be the most difficult.' (Claude Cheysson)

Such a gamble is not undertaken lightly, nor without due caution, so new structures for concertation are being established.

Therefore a Centre for Industrial Development was set up under the
Lomé Convention. This will enable traders, investors, employers and trade unions in both areas to be fully informed of what the others are doing. The Lomé Convention also has a Consultative Assembly of members of parliament from the Community and from the ACP countries, which met for the first time in June 1976. Through it, elected representatives and public opinion can be kept informed. In addition the European Commission has initiated a permanent dialogue with the unions and employers, and regularly consults industrial and agricultural trade unions on matters concerning cooperation policy. In this way the Community sets out to link the active elements in European society with the elaboration and running of its development policy.

For a successful global development policy, the Community has to be ready to assume the economic and political consequences within its own economic zone. Productivity gains, transfers or reductions in activity should be taken into account financially, socially and politically.

In return for opening its economic zone to help the Third World countries develop, the Community will benefit from a new economic zone of considerable size; an area it lacks at present. In contrast to large continents such as the United States and the USSR, the Community does not have sufficient supplies, markets and natural assets (open space, pure water, etc.) to guarantee its future. Hence the need for cooperation with the Third World. 
WHAT

THE EUROPEAN

COMMUNITY

IS DOING

\begin{abstract}
As we have seen the Community's Third World policy is based on two approaches: agreements with groups of countries, and international action.
\end{abstract}

\section{ACTION AT THE WORLD LEVEL}

At the international level, the Community tries to keep a balance between its relations with industrialized countries, and with the Third World. It does through commercial agreements, its generalized system of preferences (GSP), financial and technical aid to non-associated countries, emergency action and food aid. (These are described more fully later in the document.)

The Community is taking an active part in international discussions on the new international economic order. These include sessions of the UN General Assembly, the North-South Dialogue, the fourth UNCTAD Conference at Nairobi.

\section{Commercial agreements with Asian and Latin-American coun- tries}

Also as part of its action at world level; the Community has made commercial agreements of various kinds with twelve Asian and four Latin-American countries. The first of these came into force in 1969. The majority of the Asian countries were part of the Commonwealth and therefore entitled to special relations with the Community even before the UK's accession in 1972. After accession, the Community took note of their interest in a Decla- ration annexed to the Accession Treaty.

The Community has concluded commercial cooperation agreements with India, Bangladesh, Pakistan and Sri Lanka, as well as various sorts of textile agreements with Bangladesh, Hong Kong, India, Indonesia, Iran, Laos, Malaysia, Pakistan, the Philippines, Singapore, Sri Lanka and Thailand. Despite the importance of trade with Latin-American countries, progress recorded in their relations with the Community so far has been slow. However, non-preferential commercial agreements did come into force in 1972 with Argentina, in 1974 with Brazil and Uruguay and in 1975 with Mexico.

\section{Generalized preferences}

The concept of tariff preferences was born of the recognition of the difficulties faced by countries with young industries--the developing countries-in establishing and developing sales in the markets of industrialized countries. The aim of the system of generalized preferences is to assist the industrialization of these developing countries through reduction of customs duties. The system is thus only applied to manufacturers and processed agricultural products, and not to raw materials.

The European Community was the first industrial entity to apply a system of generalized preferences, on 1 July 1971, and has been improving it annually, both in the numbers of countries affected (111 in 1977) and in the extent of advantages granted.

First round of financial and technical help for non-associated countries

In March 1975, the European Commission submitted proposals to the Council of Ministers for an action programme covering the period 1976-80 to help those developing countries which are not signatories of regional cooperation agreements. This programme of financial and technical aid, worth 730 million u.a., is mainly directed towards the countries of Asia and Latin America and is intended to cover measures to improve agricultural output, promotion of regional cooperation and of trade, and emergency schemes.

A ministerial decision is still awaited, but in the meantime a sum of 20 million u.a. was included in the 1976 Community budget and used to help five countries(Bangladesh, India, Indonesia, Pakistan and Bolivia) and also agricultural research organizations. A sum of 45 million u.a. is being set aside in 1977.

In addition, 3.5 million u.a. were earmarked in the Community's 1976 budget for measures to promote exports and regional cooperation in Asia and Latin America, and 5.4 million are being set aside for this in 1977.

Lastly, the Community was able for the first time in 1976 to finance 'mini-projects' jointly with nongovernmental organizations. These 
The generalized preferences system is a special customs régime applied by industrialized countries to goods imported from the developing countries: it consists of cuts in customs duties (or duty free import), sometimes with quantitative limits

sometimes without. It is a system that emerged from the work of UNCTAD (the United Nations

Conference on Trade and

Development) in 1970.

There is a 'preference' in the customs sense in that the tariff cuts or exemptions are granted by the industrialized countries applying the system to developing countries in the 'Group of 77' (plus Romania for some goods), but not to each other.

The preferences are said to be 'generalized' in that in theory they are granted by all industrialized countries to all developing countries. They are also 'non-reciprocal' - the industrialized countries which grant them claim nothing in return (no 'inverse preferences') from the countries that benefit-and 'non-discriminatory' in that all developing countries benefit. It is seen as being a 'system' because all industrialized countries are supposed to grant the same concessions; but in practice there are several different patterns applied by different countries.

The European Community was the first in the industrialized world to apply a system of generalized preferences. It was introduced on 1 July 1971, and has continually been extended both in the number of countries concerned (111 in 1977) and the scale of concessions made.

The pattern of generalized preferences applied by the Community in 1977 covered 296 processed agricultural products and all industrial goods from 110 developing countries (plus

Romania for certain products), as well as from the overseas countries and territories forming part of the Community. For certain specific products, the scheme applies to a smaller number of countries.

For the 296 processed agricultura products, generalized preferences mean a cut in the level of duty in the Common External Tariff, in some cases with a quantitative ceiling applied through tariff quotas.

For the industrial goods, the duties in the Common External Tariff are not applied, though in some cases there are tariff quotas or ceilings on duty-free imports. The total potential value of imports thus freed from duty was estimated for 1977 at 1235 million EUA for processed agricultural products and 4992 million u.a. for industrial products.

For 1978 the proposals put forward by the Community should cover 305 processed agricultural goods, with considerably higher ceilings for industrial goods, and the total value of the trade benefiting should be 6400 million u.a.

In practice, however, less than $70 \%$ of the potential volume of trade benefiting from the scheme has so far been taken up by the exporting countries.

The fact that the scheme is not fully used is due to inadequate information in the countries that can benefit, to the complicated procedures involved (each exporting country has to ensure that the goods exported have with them a 'certificate of origin' proving that they were in fact manufactured there), and to the disparities between the schemes applied by the various industrialized countries.

The Community scheme is being constantly improved, and the European Parliament has commented that it can be made still better for instance by granting additional advantages to the poorest countries or adding to the list products which only they export. At the same time care has to be taken not to disrupt industries in the same sectors within the Community. Nor must the scheme be deprived of its effectiveness by granting the same concessions to all countries, whether developing or industrialized-a risk that could occur in the 'Tokyo Round' of trade negotiations in GATT. 
THE EUROPEAN COMMUNITY

\section{AND ASIA}

From the above outline of action at the world level it will be clear that in recent years the European Community has greatly developed its trade and cooperation links with the countries of the Indian sub-continent and South-East Asia. All have since 1971 been beneficiaries of the EEC's

Generalized Scheme of Preferences (GSP), from which India and Pakistan have been among the leading beneficiaries. Under the GSP the Community applies zero tariffs to all industrial products, including textiles, imported from developing countries, though subject to quantitative ceilings for a limited number of sensitive products. The Scheme has been expanded in its scope in successive stages to include a widening range of processed agricultural products as well as one unprocessed item. tobacco. The inclusion of additional products to the Scheme has in many cases been on the request of individual Asian countries.

The GSP has been a major instrument employed by the Community to solve problems arising from the Commonwealth Preferences System and the alignment of the British tariff on the Common Customs Tariff, to be completed on 1 July 1977.

However, during the negotiations for British accession to the Community, agreement was reached that should trade problems arise for

Commonwealth countries which the GSP could not resolve the Community would meet with the country concerned to seek 'appropriate solutions' to the problems. This undertaking was embodied in the "Joint

Declaration of Intent' (JDI) annexed to the Accession Treaty. Apart from the successive improvements to the GSP offer mentioned above the JDI has led to the conclusion of Commercial Cooperation Agreements (CCA) between the Community and India, Pakistan, Sri Lanka and Bangladesh as well as a Joint Study Group (JSG) between the Commission and the five countries of ASEAN (Indonesia, Thailand, Philippines, Malaysia and Singapore). Both

arrangements aim at stimulating wide-ranging co-operation between the Community and the partner Asian countries.

The mainspring of each of the CCAs is a Joint Commission of representatives of the

Commission and the partner country meets at regular intervals, as does the EC/ASEAN Joint Study Group. Asia has so far been the principal beneficiary of the financial and technical aid for non-associated countries. bodies generally finance small schemes of local interest (village wells, farming equipment) which cannot be covered by international organizations. The Community put up 2.5 million u.a. in 1976 and 4 million were spent in 1977.

\section{Food aid}

For the last twenty years the developing countries have been experiencing an unprecedented food crisis. The population explosion, scarcity of technical and financial resources, and the strength of local custom are all obstacles to improving agricultural yield and, with it, food supply. Since 1972 a series of events combined to give the situation a dramatic turn. Adverse atmospheric conditions, particularly drought, have affected numerous regions of the world. The most notable are the Sahel, Ethiopia, Somalia and Bangladesh.

The shortages of 1972 were aggravated by world inflation, monetary instability and speculation following the drop in food production, particularly cereals. The oil and raw materials 'crisis' increased the price of fertilizer, pesticides and other production materials in the developing countries. This accelerated the partial failure of the "green revolution', the name given to the transformation of agricultural techniques in the developing countries that had been supposed to bring about a spectacular increase in yield.

Faced with world-wide food shortages the responsibility of the indus- trialized countries, particularly Europe, is evident, since large quantities of foodstuffs are produced in temperate zones. The European Community has been active in distributing food aid since 1968 combining the action of its own Member States with specific Community measures. 
FOOD AID

THE BALANCE SHEET AFTER TEN YEARS
The European Community has been involved in food aid operations since 1968, first of all with cereals and then, since 1970, with other products (milk powder, butteroil, sugar, egg powder). Total cereal aid has amounted to 9.2 million tonnes, worth some 1100 million $u . a$. including national aid from EEC Member States. Specific Community aid for other products came to 567 million u.a.

\section{EEC FOOD AID (1968-77)}

\begin{tabular}{|c|c|c|c|c|}
\hline & \multicolumn{2}{|c|}{ Quantity ( 1000 tonnes) } & \multicolumn{2}{|c|}{ Value (million u.a.) } \\
\hline & $1968-76$ & 1977 & $1968-76$ & 1977 \\
\hline CEREALS & 9161 & 1287 & $1141^{1}$ & $145^{1}$ \\
\hline Community action & 3800 & 721 & $502^{1}$ & $81^{1}$ \\
\hline National action & 5361 & 566 & $639^{1}$ & $64^{1}$ \\
\hline OTHER PRODUCTS ${ }^{2}$ & - & - & 567 & $86^{3}$ \\
\hline Milk & 460 & 105 & 287 & 41 \\
\hline Butteroil & 187 & 45 & 272 & 47 \\
\hline Sugar & 18 & - & $7^{r}$ & - \\
\hline Eggs & 0.5 & - & 1 & - \\
\hline
\end{tabular}

Estimate at world prices.

2 Community action only.

Provisional figure.

\section{Emergency financial aid}

\section{EMERGENCY FUND}

One of the most disastrous effects of the 1973-74 economic crisis was that it put those developing countries which had no raw materials in a desperate position. Made bankrupt by the crisis, such countries could only have recourse to special outside aid.

That is why, in March 1974, the European Commission proposed that a world emergency fund be set up, with US $\$ 3000$ million worth of resources, to help those developing countries most heavily hit by the rise in the prices of raw materials. In April 1974 the United Nations special session took up this idea and adopted it. By April 1975, the European Community had contributed over US $\$ 720$ million as against the 500 million envisaged as its contribution a year earlier. The contribution made by the Community as such was US $\$ 292$ million, whilst the Member States individually put up a further US $\$ 430$ million.

\section{DISASTER AID}

In addition to special action, the Community is always in a position to step in to help countries which have been hit by natural disasters : it has a special heading for this in its budget $(800000$ u.a. are earmarked for this in 1977).

There is also a contribution to UNRWA (United Nations Relief and Works Agency), the UN agency which is helping Palestinian refugees, written into the overall Community budget. 


\section{ACTION AT REGIONAL LEVEL}

The Mediterranean is an area characterized by a uniform climate, soil and agricultural production... and similar industrial structures. The Community is an integral part of this Mediterranean world in its southern regions (South of France, Italy) and finds itself as a consequence in competition with the agricultural producers of these countries for whom it is also the principal outlet. On the other hand the Community does export a large part of its cereals, meats, and dairy products to these countries. It satisfies a large part of their need for industrial products equipment and manufactured goods. The Community finds itself in an ambivalent position towards its Mediterranean partners, being both a competitor and a privileged partner. This does not make it easy to develop a coherent Community policy towards them.'

(Report from European Parliament on the Community's Mediterranean policy.)
Alongside its action at world level and with the assistance it is giving to establish a new type of relationship between industrialized countries and the Third World, the European Community is trying to encourage stronger contractual relations with specific countries or groups of countries. These are basically the developing countries party to the Lomé Convention-the ACP States and the developing countries bordering the Mediterranean. The Community intends establishing privileged relations with them because their economies complement its own, because of the existence of historic links or simply because they are near at hand. Compared to what other industrialized nations are doing this is an original approach because it combines a variety of instruments to attain a single goal: financial cooperation, access to the Community's market, trade cooperation, industrial cooperation, stabilization of export earnings, and institutional mechanisms, etc.

The Community has taken up a challenge here : that of setting up a "new order' in its relations with these countries at the risk of seeing them become its closest competitors.

\section{The Mediterranean countries}

The special ties of the Community with the whole Mediterranean area are behind a whole series of agreements of different types and dates with both northern and southern Mediterranean countries. ${ }^{1}$

As early as 1972, the European Commission proposed a 'global approach' to the Mediterranean countries. The idea was to provide a coherent framework for the agreements already signed or to be signed in the future. The countries on the northern shores of the Mediterranean are European and thus potential Community members, whilst those on the southern side are developing countries; but this should not be allowed to obscure the fact that the relations of the Community countries with their Mediterranean neighbours constitute a whole, geographically, economically, culturally and historically.

So there is no conflict between the two approaches - to the Third World countries around the Mediterranean on one side, and to the Mediterranean area as a whole on the other. The two can coexist, for both reflect real situations. This is true, too, in the case of the EuroArab Dialogue.

\footnotetext{
1 The countries on the northern shores of the Mediterranean are geographically part of Europe and are thus seen in principle as future Community members (negotiations with Greece began in 1976). Only the countries on the southern shores come under the development policy dealt with here.
} 
COMMUNITY AGREEMENTS WITH MEDITERRANEAN DEVELOPING COUNTRIES

The agreement between the Community and Israel which came into force on 1 July 1975 was the first step towards practical application of the global approach to the Mediterranean. It was followed by cooperation agreements with the Maghreb countries-Algeria, Morocco and Tunisia-and the Mashreq countries-Egypt, Jordan, Syria and Lebanon-which were signed in April 1976, January 1977 and May 1977.

In February 1977 the agreement with Israel, which provides for the establishment of a free trade area; was extended by an additional protocol aimed at bringing about a similar form of cooperation to that agreed on with the Maghreb and Mashreq countries, thus enabling the Community to maintain and develop politically balanced relations with all the countries round the shores of the Mediterranean.
The commercial part of these agreements grants free access to the markets of the Community for industrial goods from its partners (except where there are temporary derogations for sensitive products) and involves concessions covering the main agricultural products which they export to the Community. Given the current level of development of the Maghreb and Mashreq countries the agreements with them do not provide at this stage for reciprocal concessions to the Community. In the case of Israel, the free trade area for industrial products has to be fully effective by 1989 at the latest.

Today 800000 Maghreb nationals -500000 Algerians, 200000 Moroccans and 100000 Tunisianswork in Europe. The three agreements stipulate that they should benefit from the same pay and working conditions as European workers, and that they should have the right to the same social advantages in every Community country. In addition, nationals of these three countries working successively in

\section{FINANCIAL COOPERATION WITH MEDITERRANEAN DEVELOPING COUNTRIES} (1977-81)

(in million u.a.)

\begin{tabular}{lccrrrrrr}
\hline & \multicolumn{2}{c}{ Algeria Morocco Tunisia } & Egypt & Jordan & Syria Lebanon & Israel \\
Normal & 70 & 56 & 41 & 93 & 18 & 34 & 20 & 30 \\
ElB loans & 19 & 58 & 39 & 14 & 4 & 7 & 2 & - \\
Special loans & 25 & 16 & 15 & 63 & 18 & 19 & 8 & - \\
Grants & 114 & 130 & 95 & 170 & 40 & 60 & 30 & 30 \\
\hline Total & 114 & & & & & & &
\end{tabular}

several Community countries will be able from now on to cumulate their periods of employment, insurance and residence in each country for purposes such as allowances and payments for old age, death, invalidity, health care, and family allowances when their families are in fact resident in the Community. Such benefits could only be possible through such a Community-level agreement.

The financial and technical cooperation provided for in the three agreements will help in efforts being made by the Maghreb countries to diversify their economies, to industrialize, and to modernize their agricultural sectors-possibly in collaboration with the oil-exporting countries.

The Community will participate in industrial development programmes by providing finance, contacts with the European traders and investors and access to facilities, technology and patents. Cooperation with Algeria and Tunisia in the energy sector is also provided for. For each of the agreements a Council of Ministers will manage the arrangements and facilitate exchanges between the European Parliament and national parliaments. 


\section{THE EURO-ARAB DIALOGUE}

In December 1973 at the 'Summit' of the Nine in Copenhagen, the heads of government replied to an approach by Arab ministers and confirmed the importance they attached to the search for long-term cooperation in technical, economic and cultural areas.

Despite initial difficulties in getting the dialogue started the Nine managed to conduct a joint negotiating position with the Arab-League countries.

The subjects discussed covered cooperation in the following

fields: industry, infrastructure, agriculture, trade, finance, science and technology and social and labour aspects.

The Euro-Arab Dialogue,

undertaken jointly by the Nine and the Member States of the Arab League, is a vast long-term project, that could lead to bilateral agreements between Arab and European countries or between Arab countries and the

Community las was the case with the Mediterranean countries,

(Algeria, Morocco, etc.) Three Arab League countries have signed the ACP-EEC Lomé

Convention-Mauritania, Somalia and the Sudan.
TRADE BETWEEN THE EEC AND THE ARAB COUNTRIES (1975)

(in million u.a.)

\begin{tabular}{lrc}
\hline & EEC IMPORTS & EEC EXPORTS \\
\hline World (excluding EEC) & $118608.7(100 \%)$ & $116099.0(100 \%)$ \\
Arab League & & \\
Morocco & $23530.3(19.8 \%)$ & $14382.8(12.4 \%)$ \\
Algeria & 757.6 & 983.1 \\
Tunisia & 1926.7 & 2651.3 \\
Libya & 335.8 & 667.0 \\
Egypt & 2475.2 & 1850.5 \\
Sudan & 299.3 & 1268.4 \\
Somalia & 158.2 & 280.9 \\
Mauritania & 10.5 & 55.9 \\
Lebanon & 115.4 & 100.1 \\
Syria & 51.6 & 589.6 \\
Iraq & 436.2 & 548.8 \\
Jordan & 2651.5 & 1744.2 \\
Saudi Arabia & 7.7 & 205.8 \\
Kuwait & 8566.6 & 1394.2 \\
Bahrein & 2369.9 & 561.7 \\
Qatar & 44.4 & 172.1 \\
United Arab Emirates & 688.8 & 179.2 \\
Oman & 2266.0 & 739.9 \\
Yemen (AR) & 360.0 & 300.9 \\
Yemen (PDR) & 1.6 & 58.4 \\
& 7.2 & 29.8 \\
\hline
\end{tabular}

Note: The Arab countries are the Community's leading trade partners (taking $12 \%$ of EEC exports, $20 \%$ of imports), followed by the United States ( $11 \%$ of exports, $16 \%$ of imports), and third East Europe $(10 \%$ of exports, $7 \%$ of imports). 


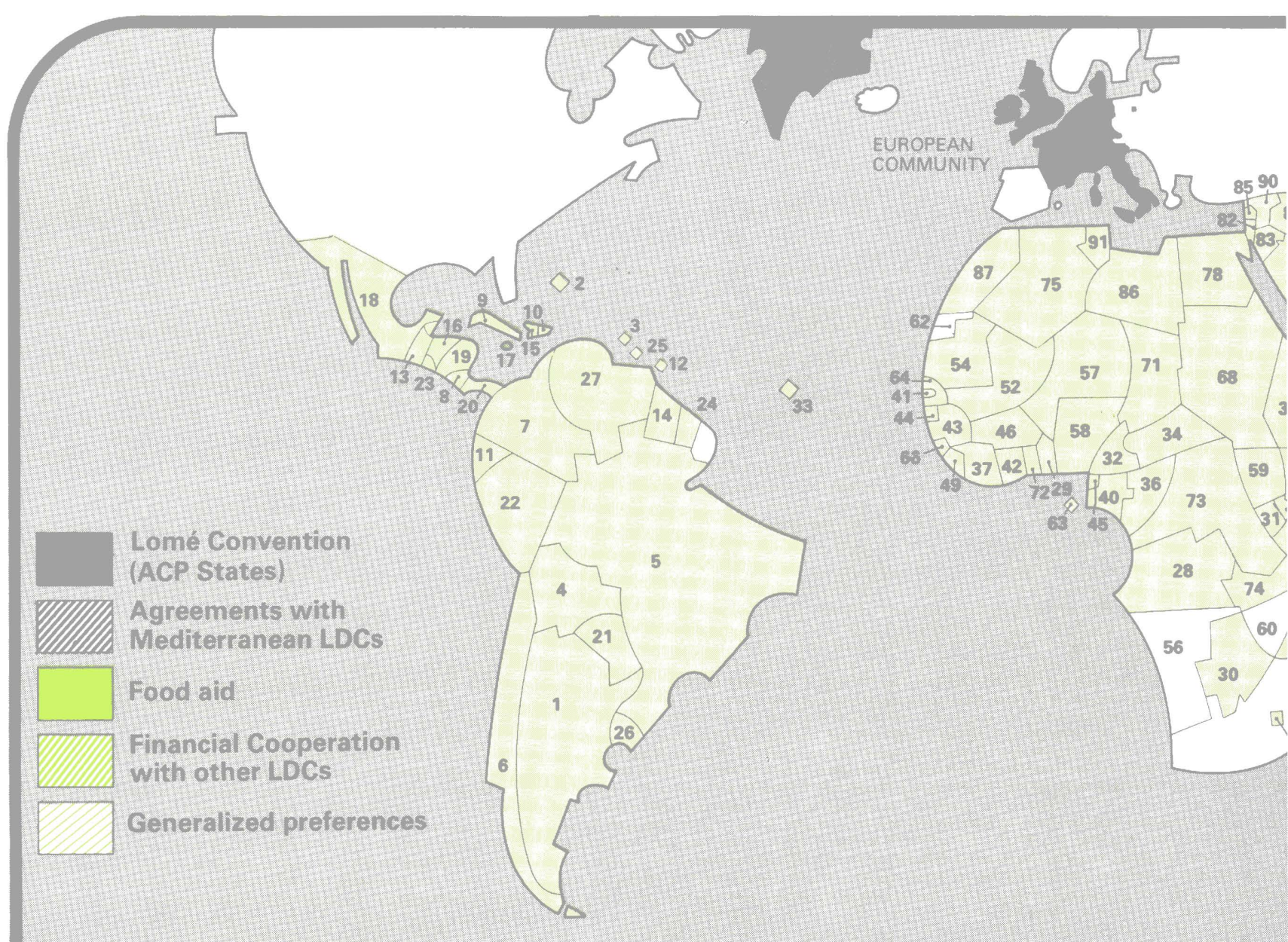

\begin{tabular}{|l|l|l|}
\hline $\begin{array}{l}\text { LATIN } \\
\text { AMERICA }\end{array}$ \\
\hline 1 Argentina \\
\hline 2 Bahamas \\
\hline 3 Barbados \\
\hline 4 Bolivia \\
\hline 5 Brazil & & \\
\hline 6 Chile & & \\
\hline 7 Colombia & & \\
\hline 8 Costa Rica & & \\
\hline 9 Cuba & & \\
\hline 10 Dominican Republic & & \\
\hline 11 Ecuador & & \\
\hline 12 Grenada & & \\
\hline 13 Guatemala & & \\
\hline 14 Guyana & & \\
\hline 15 Haiti & & \\
\hline 16 Honduras & & \\
\hline 17 Jamaica & & \\
\hline 18 Mexico & & \\
\hline 19 Nicaragua & & \\
\hline 20 Panama & & \\
\hline 21 Paraguay & & \\
\hline 22 Peru & & \\
\hline 23 Salvador & & \\
\hline 24 Surinam & & \\
\hline 25 Trinidad and Tobago & & \\
\hline 26 Uruguay & & \\
\hline 27 Venezuela & & \\
\hline
\end{tabular}

\begin{tabular}{l}
$\begin{array}{l}\text { AFRICA SOUTH } \\
\text { OF THE SAHARA }\end{array}$ \\
\hline 28 Angola \\
\hline 29 Benin
\end{tabular}




\section{Lomé Convention ${ }^{1}$}

The Lomé Convention signed between the European Community and 46 countries of Africa, the Caribbean and Pacific, ${ }^{2}$ is an historic event and a decisive step towards a new economic order. The Lomé Convention sets an example for regional agreements between industrialized countries and developing countries throughout the world. The Lomé Convention is independent of the aid and cooperation policies of the EEC countries. It is also more complete and more ambitious. It introduces a number of new elements in CommunityThird World relations into international law and institutions.

Thus:

- The Lomé Convention recognizes de jure in an international treaty the inequalities existing between the signatories (EEC, ACP) and between the ACP States themselves. For example, the leastdeveloped ACP States are given special financial aid.

- Through 'Stabex', the system for stabilizing ACP export earnings, the Lomé Convention has introduced a sort of international social security scheme to protect countries which depend on sales of their agricultural products against bad years, and compensate them for the instability resulting from the play of free market forces (health insurance and unemployment insurance).

- In the case of sugar cane exports to the EEC from the ACP countries, the Lomé Convention provides for a reorganization of the market for a particular commodity. It offers producer countries a minimum price indexed to the income of European sugarbeet producers. This is a major innovation.

- To keep relations between the $E E C$ and $A C P$ on the right track, the Lomé Convention has catered for permanent concertation through such general institutions as the ACP-EEC Council of Ministers, the ACP-EEC Consultative Assembly of parliamentarians or through specific bodies such as the Centre for Industrial Development, and the Committee for Industrial Cooperation. These in no way infringe the sovereignty of the Community's partners in running their own affairs. This approach is in the spirit of the Declaration on the international economic order adopted by the UN General Assembly on 1 May 1974.

\footnotetext{
1 For more detailed information on the Lomé Convention see Commission document No 129/76/X/F.

2 Six more countries signed the Convention in 1977: Surinam, the Seychelles, the Comoros, Papua, New Guinea, Sao Tome and Principe, and Cape Verde.
}

\section{THE EEC-ACP LOMÉ CONVENTION COVERS SEVEN MAIN AREAS}

1. Trade cooperation: this covers the trade arrangements (tariff and non-tariff rules, rules of origin) between the ACP and the EEC and trade promotion of ACP products. 2. Stabilization of export earnings for the ACP States is guaranteed by the EEC through its 'Stabex' system.

3. The provisions concerning $A C P$ sugar contain a commitment for buying by the EEC and for supplying by the ACP producer States for specified quantities at guaranteed prices.

4. The industrial cooperation provisions aim at facilitating the industrialization of the ACP States, in particular through the transfer and adaptation of technology. An EECACP Committee for Industrial Cooperation has been set up and the Joint Centre for Industrial Development is acting as a catalyst for investment in Third World industry. 5. Financial and technical cooperation : 3390 million u.a. will be transferred from the EEC to the ACP States during the five-year duration of the Convention (up to 1.3.1980 for financial cooperation). As well as finance for investment projects put forward by the ACP countries, the Lomé Convention provides figures for regional cooperation covering two or more ACP countries, for commercial and industrial promotion, for small- and medium-sized firms and for local 'microprojects'. The European Development Fund also covers the Stabex system. 


\section{HOW THE 'STABEX' SYSTEM WORKS}

Stabex lexport receipts stabilization system) is a sort of 'insurance policy against bad years'. It covers the 46 States which signed the Lomé

Convention and concerns 29 products, arranged in 12 groups; products made from ground nuts, coffee, cotton, coconut, palm trees and palm nuts; hides and skins; wood products; tea, raw sisal and iron ore.

Stabex covers revenues from the export of these products when they represent more than $7.5 \%$ of the total export receipts of the country concerned. That is the 'threshold of dependence'. This threshold is reduced to $2.5 \%$ in the case of the least-developed African, Caribbean and Pacific countries, those which are landlocked or islands, or those designated as least-developed in the Lomé Convention.

The second condition for the application of the scheme is that the EEC guarantees only receipts from exports to the Community, and only if they are consumed or processed in Europe (thus ruling out re-export). However, in the cases of Guinea-Bissau, Ethiopia, Rwanda, Burundi and Swaziland, which export so little to the Community that the scheme would have been of no value to them, Stabex applies to all their exports of the products concerned.
The conditions which bring Stabex into play are clearly set out. For each product and for each ACP country, a 'reference level' is drawn up each year, on the basis of export receipts over the four preceding years. When the receipts in any one year drop below this level by a certain percentage (called the

'dependence threshold'), the country involved calls on the Community to pay it a sum corresponding to the difference. If all the conditions are fulfilled, the Community thus pays the country the 'shortfall'. The country will pay it back when its export receipts are expanding-except in the case of the 34 least-developed countries, which are exempted from repayment.

Up to September 1977, 40 conventions covering Stabex payments had been signed with 29 ACP States, for a total of 104 million u.a.

At the Interministerial Council in Fiji in April 1977, the following products were added to the Stabex list: vanilla, cloves, pyrethrum, wool, mohair, gum arabic and ylang-ylang, and the following countries were accorded Stabex for exports in all directions: Western Samoa, the Seychelles, the Comoros, Tonga and Lesotho. 
Financial cooperation is wideranging and calls for close EEC-ACP collaboration. It includes special advantages for the leastdeveloped, landlocked and island ACP countries.

6. The provisions relating to establishment, services, payments and capital movements ensure nondiscriminatory treatment of any ACP companies, firms and nationals.

7. The ACP-EEC institutions (Council of Ministers, Consultative Assembly) provide for joint management of the terms of the Lome Convention.
THE APPLICATION OF THE LOMÉ CONVENTION (SITUATION AS OF 1 SEPTEMBER 1977)

The Lomé Convention was signed on 28 February 1975, in Lomé, Togo. The trade provisions came into force on 1 July 1975, before ratification by all $A C P$ and $E C$ Member States. After this ratification, the Convention came fully into force on 1 April 1976. The Convention lasts five years, to 1 March 1980.

(in million EUA)

Overall financial resources for period 1.4.1976 to 1.3 .1980
Sums committed as of 8 September 1977

\begin{tabular}{|c|c|c|c|c|c|}
\hline EDF & & $3054^{1}$ & $\mathrm{EDF}^{2}$ & & 910 \\
\hline - grants & 2137 & & - grants & 655 & \\
\hline - loans on & & & - loans on & & \\
\hline $\begin{aligned} & \text { special terms } \\
& \text { - risk capital }\end{aligned}$ & $\begin{array}{r}440 \\
97\end{array}$ & & $\begin{aligned} & \text { special terms } \\
& \text { - risk capital }\end{aligned}$ & $\begin{array}{r}122 \\
29\end{array}$ & \\
\hline - Stabex & 380 & & - Stabex & 104 & \\
\hline EIB & & 390 & EIB & & 86 \\
\hline Total & & 3444 & Total & & 996 \\
\hline
\end{tabular}

1 Following the accession of 6 new States to the Lomé Convention, 54 million EUA were added to the original sum of 3000 million EUA.

2 Including regional projects and administrative costs. 


\section{ANNEXES}

\section{EEC - THIRD WORLD RELATIONS}

Initials of the main bodies concerned with the developing countries

The historical background

The economic relations of the European Community with countries with which it has contractual agreements

Exports of developing countries and industrialized countries

External public debt of the developing countries

Bibliography

THE EUROPEAN COMMUNITY

What it does and for whom

European Community institutions

The major dates of the European Community

How the institutions of the European Community work 


\section{INITIALS OF THE MAIN BODIES CONCERNED WITH THE DEVELOPING COUNTRIES}

DAC Development Assistance Committee

EDF European Development Fund

EEC European Economic Community

EIB European Investment Bank

FAO Food and Agriculture Organization

GATT General Agreement on Tariffs and Trade

IBRD International Bank for Reconstruction and Development

IDA International Development Association

IFAD International Fund for Agricultural Development

IMF International Monetary Fund

ILO International Labour Organization

OECD Organization for Economic Cooperation and Development

OPEC Organization of Petroleum Exporting Countries

UNCTAD United Nations Conference on Trade and Development

UNDP United Nations Development Programme

UNEP United Nations Environment Programme

UNESCO United Nations Educational Scientific and Cultural Organization

UNICEF United Nations Childrens' Fund

UNIDO United Nations Industrial Development Organization

UNO United Nations Organization

WHO World Health Organization 


\section{EEC - THIRD WORLD RELATIONS}

THE HISTORICAL BACKGROUND HOW THE DEVELOPMENT POLICY BEGAN

When the Treaty of Rome establishing the common market was signed in 1957 by the original Six - the Federal Republic of Germany, Belgium, France, Italy, Luxembourg and the Netherlands - they decided to contribute collectively to the development of certain countries. At the time, these countries were the overseas dependencies of Belgium, France, Italy and the Netherlands. They became 'associated' with the Community.

This policy, however, was soon to be modified. At the beginning of the 1960 s the majority of developing countries covered by the Treaty of Rome gained their independence. Almost all of these countries decided to maintain their links with the common market. These 18 States-the Associated African States and Madagascar (AASM)-negotiated a new association agreement in 1963 (Yaoundé Convention) then another in 1969 (Yaoundé Convention II). Both agreements lasted for five years.

These Conventions were conceived as contractual agreements linking the European Community on the one side with each of the AASM countries on the other. They contained commercia and financial arrangements (European Development Fund - EDF) and were run by an on-going dialogue in institutions (a ministerial Council, a parliamentary Assembly) with parity representation.

\section{A DOUBLE DEVELOPMENT}

This geographically-limited policy was subjected to a double test: internal change in the Community, which grew from six to nine members; and the change in the nature and needs of the Third World.
In negotiations for the accession of the three new Member States (Denmark, Ireland and the United Kingdom) it was agreed that the developing countries in the British Commonwealth should receive similar status to the AASM countries. It has in fact been foreseen in 1963 by the signatories of the first Yaounde Convention, that while still preserving advantages that AASM had already gained, other developing countries should be offered access to contractual agreements with the Community.

In 1969 the Arusha Convention was signed between the EEC and the East-African States (Kenya, Uganda, Tanzania) and in May 1972 Mauritius became party to the second Yaoundé Convention.

A new contractual agreement, replacing the Yaoundé set-up, was negotiated between the Community of Nine and 46 independent States in Africa, the Caribbean area and the Pacific.

The other change that was going on was in the Third World and its attitude to the European Community.

The early years of the European Community coincided with two world developments of world-wide importance : the independence of the majority of colonial countries in the 1960 s and the organization and grouping of developing countries within international or regional organizations. New trade flows emerged, new relations developed between States and, as a result, the collective objectives of the Third World emerged for the first time. The emergent European Community at once became one of the leading economic entities in the world. As such, it could not divorce from the changes taking place in international economic relations. More and more developing countries-Mediterra- 
nean, Asian and Latin American-requested commercial agreements with the Community. Developing countries without contractual agreements with the Community began to demand free access for their products.

TOWARD A GLOBAL POLICY

It has taken more than 15 years for the Community to make practical progress towards an overall policy towards the developing countries. Essentially, this is because the Treaty of Rome did not give the Community any explicit or general mandate in this field. This is hardly surprising since the Treaty of Rome was conceived in circumstances radically different from today. Development and cooperation is a thus relatively recent phenomenon for the Community. Lacking the power to establish in a small move a joint conception of its relations with the developing countries the Community was, for a long time, only able to put together gradually the elements of a cooperation policy, adapting them gradually as circumstances allowed. The broad and clear mandate given by the 1972 Paris Summit to work out a "global cooperation and development policy', was thus a decisive step.

At the same time, the legal and political obstacles, that prevented this happening earlier, were removed. The clash between the 'regionalists'-and those who maintained that the Community should deal with the problems of all the world's developing countries, became less acute, since the Community has been given the power to act on two fronts simultaneously:

- continuance and extension of cooperation in a regional context;

- progressive implementation of an overall policy at world level.

The regional and world dimensions of Community cooperation policy were in future to be complementary aspects of the same approach, not (as had been the case until 1972) as alternatives.

Both negotiations leading to the Lomé Convention and agreements worked out with Mediterranean countries followed this approach, as did negotiations broadening the Community's policy on generalized preferences. So too did additional instruments developed for financial and technical cooperation with non-associated countries, and the emergency fund for developing countries most affected by international price movements in 1973-74.

Though it is not strictly accurate to talk of the Community as an 'instrument' of cooperation, it did however play a fundamental role between 1973 and 1976 in bringing about fairer and more balanced relations between the industrialized and the developing countries. Although it has frequently worked with other industrialized countries whose motivations and interests did not necessarily coincide with its own, the Community has been able to operate using its own resources.

In effect the Community has helped to stimulate other rich countries. It was an active participant in major international discussions: sessions of the UN General Assembly in New York; the North-South Dialogue in Paris; at conferences of UN specialized agencies such as the Industrial Development Organization Conference (UNIDO) at Lima and the 4th session of UNCTAD in Nairobi; and at the GATT multilateral trade negotiations. 


\begin{tabular}{|c|c|c|c|c|c|}
\hline & $\begin{array}{r}\text { ACP } \\
\text { STATES }{ }^{1}\end{array}$ & $\begin{array}{r}\text { MAGHREB } \\
\text { COUNTRIES }^{2}\end{array}$ & $\begin{array}{r}\text { MASHREQ } \\
\text { COUNTRIES }^{3}\end{array}$ & ISRAEL & TOTAL \\
\hline Population (in millions) & 268 & 36 & 48 & 3 & 355 \\
\hline \multicolumn{6}{|l|}{ Exports of the EEC (1975) } \\
\hline \multirow{2}{*}{$\begin{array}{l}\text { in million EUA } \\
\text { In \% of total exports } \\
\text { outside EEC }\end{array}$} & 7590 & 4301 & 2613 & 1220 & 15724 \\
\hline & $6.5 \%$ & $3.7 \%$ & $2.2 \%$ & $1.1 \%$ & $13.5 \%$ \\
\hline \multicolumn{6}{|l|}{ Imports of EEC (1975) } \\
\hline \multirow{2}{*}{$\begin{array}{l}\text { in million EUA } \\
\text { In } \% \text { of total imports } \\
\text { of the EEC }\end{array}$} & 8159 & 3020 & 795 & 538 & 12512 \\
\hline & $6.9 \%$ & $2.5 \%$ & $0.7 \%$ & $0.5 \%$ & $10.6 \%$ \\
\hline \multicolumn{6}{|l|}{ Trade balance of the } \\
\hline \multicolumn{6}{|l|}{$\begin{array}{l}\text { Financial aid envisaged } \\
\text { by the agreements }\end{array}$} \\
\hline \multirow{3}{*}{$\begin{array}{l}\text { in million EUA } \\
\text { Period of application } \\
\text { of financial aid }\end{array}$} & 3444 & 339 & 300 & 30 & 4113 \\
\hline & & & & & \\
\hline & $\begin{array}{r}1.4 .1976 \\
\text { until } 1.3 .1980\end{array}$ & $\begin{array}{r}\text { until } \\
31.10 .1981\end{array}$ & $\begin{array}{r}\text { until } \\
31.10 .1981\end{array}$ & $\begin{array}{r}\text { until } \\
31.10 .1981\end{array}$ & \\
\hline
\end{tabular}

146 ACP States who signed the Lomé Convention on 28.2.1975.

2 Algeria, Morocco, Tunisia.

3 Egypt, Jordan, Lebanon, Syria.

\section{EXPORTS OF DEVELOPING COUNTRIES (1970-76)}

\begin{tabular}{lrrrr}
\hline & $\begin{array}{r}\text { Total } \\
\text { exports }\end{array}$ & \multicolumn{2}{c}{ Destinations in \% of total exports } \\
\cline { 3 - 5 } Year & $\begin{array}{r}\text { (in billion } \\
\text { US dollars) }\end{array}$ & $\begin{array}{r}\text { Industrialized } \\
\text { countries }\end{array}$ & $\begin{array}{r}\text { Socialist } \\
\text { countries }\end{array}$ & $\begin{array}{r}\text { Developing } \\
\text { countries }\end{array}$ \\
\hline 1970 & 55.0 & $73.9 \%$ & $5.7 \%$ & $19.5 \%$ \\
1971 & 62.4 & $73.5 \%$ & $4.9 \%$ & $20.1 \%$ \\
1972 & 74.9 & $74.4 \%$ & $4.6 \%$ & $20.6 \%$ \\
1973 & 111.1 & $73.3 \%$ & $4.6 \%$ & $20.6 \%$ \\
1974 & 219.9 & $74.5 \%$ & $4.6 \%$ & $21.2 \%$ \\
1975 & 210.0 & $71.3 \%$ & $4.1 \%$ & $23.0 \%$ \\
1976 (P) & 251.0 & $72.9 \%$ & $21.9 \%$ \\
\hline
\end{tabular}

$(\mathrm{P})=$ provisional.

Source: World Bank, Annual Report 1977.

\section{EXPORTS OF INDUSTRIALIZED COUNTRIES (1970-76)}

\begin{tabular}{lrrrr}
\hline & $\begin{array}{r}\text { Total } \\
\text { exports }\end{array}$ & \multicolumn{2}{c}{ Destinations in \% of total exports } \\
\cline { 4 - 5 } Year & $\begin{array}{r}\text { (in billion } \\
\text { US dollars) }\end{array}$ & $\begin{array}{r}\text { Industrialized } \\
\text { countries }\end{array}$ & $\begin{array}{r}\text { Socialist } \\
\text { countries }\end{array}$ & $\begin{array}{r}\text { Developing } \\
\text { countries }\end{array}$ \\
\hline 1970 & 224.8 & $76.7 \%$ & $4.0 \%$ & $18 \%$ \\
1971 & 251.4 & $76.8 \%$ & $3.8 \%$ & $18.8 \%$ \\
1972 & 298.6 & $77.2 \%$ & $4.3 \%$ & $17.9 \%$ \\
1973 & 407.8 & $76.4 \%$ & $4.8 \%$ & $18 \%$ \\
1974 & 543.7 & $73.3 \%$ & $6.2 \%$ & $20.9 \%$ \\
1975 & 579.6 & $69.5 \%$ & $5.5 \%$ & $23.9 \%$ \\
1976 (P) & 645.3 & $71.1 \%$ & $22.9 \%$ \\
\hline
\end{tabular}

$(\mathrm{P})=$ provisional.

Source: World Bank, Annual Report 1977. 
EXTERNAL PUBLIC DEBT OF 84 DEVELOPING COUNTRIES

as of 31 December 1975, in million US dollars ${ }^{1}$

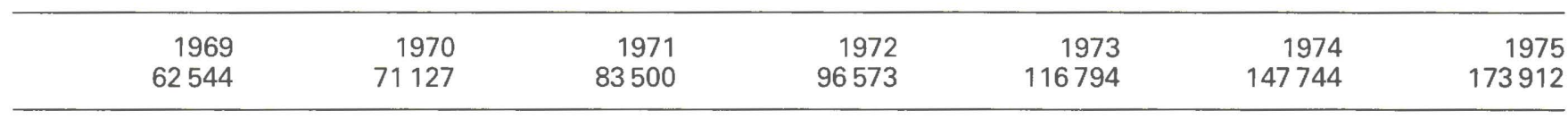

Source: World Bank, Annual Report 1976.

1 Round figures.

\section{EXTERNAL PUBLIC DEBT OF 84 DEVELOPING COUNTRIES BY TYPE OF CREDITOR}

as of 31 December 1975, in million US dollar ${ }^{1}$

\begin{tabular}{lr} 
Bilateral public creditors & 70291 \\
Multilateral creditors & 37020 \\
Private creditors: & 18734 \\
- Suppliers & 40558 \\
- Banks & 7309 \\
- Others & 173912 \\
\hline TOTAL CREDITORS & 1734
\end{tabular}

Source: World Bank, Annual Report 1976.

1 Round figures.

\section{BIBLIOGRAPHY}

\section{Reference works}

- Development aid: Fresco of Com munity action tomorrow - Supplement $8 / 74$ to the Bulletin of the European Communities

- Lomé Dossier lofficial text of the ACP-EEC Lomé Convention and commentaries, reprint of 'The Courrier' No 31)

- The Lomé Convention, Europe Africa, the Caribbean and Pacific Analytical guide to the terms of the Lomé Convention, Document No $129 / 76 / \mathrm{X} / \mathrm{F}$

\section{Other publications}

- 'The Courrier', European Community - Africa, the Caribbean, the Pacific, bi-monthly, published by the Commission of the European Communities

- Background notes of the Information Directorate-General of the Commission, notably:

No 114/76 The European Unit of Account

No 115/76 List of agreements signed by the European Community with third countries

No 119/76 EEC - Tunisia

No 120/76 EEC - Algeria

No 121/76 EEC - Morocco

No 142/76 EEC - Egypt

No $143 / 76$ EEC - Syria

No 144/76 EEC - Jordan

No 165/76 EEC - Israel

No $147 / 77$ EEC - Lebanon
- The series 'Information Memo' includes:

1976 No P. 14 The cooperation agreements between the European Community and Algeria, Morocco and Tunisia

No P. 100 The cooperation agreements between the European Community and Egypt, Jordan and Syria

1977 No P. 29 The ACP-EEC Convention of Lomé: One year after its entry into force.

- In the series 'European documentation': 'The European Community and the developing countries'. 


\section{THE EUROPEAN COMMUNITY}

\section{WHAT IT DOES AND FOR WHOM}

The European Community was established in stages, by three treaties, one in 1951 and two in 1957.

- The Treaty of Paris, signed in 1951 created the European Coal and Steel Community (ECSC) to pool the coal and steel production of the six founder countries (the Federal Republic of Germany, Belgium, France, Italy, Luxembourg and the Netherlands).

- The Treaty of Rome, signed in 1957

by the same countries, instituted the European Economic Community-better krown as the common market-with the aim of facilitating trade and bringing about the gradual integration of the economies of the Six, by establishing common policies. - A parallel treaty, also signed by the Six in Rome in 1957, instituted the European Atomic Energy Community, known as Euratom, with the aim of ensuring the full use of resources in developing nuclear energy for peaceful purposes. These treaties can be said to form the constitution of the European Community. They lay down the Community's objectives, fix the outlines of its activity, and set out how its institutions are to work.

In 1967 the institutions of the three original Communities, while remaining distinct in international law, were merged, so that the European Community now has a single set of institutions: the Council, composed of Member States' representatives; the Commission, an independent body responsible for initiating and executing policy; the Court of Justice; and the European Parliament.

In January 1972 three new countries (Denmark, Ireland and the United Kingdom) joined the original Six, in a treaty which came into force on 1
January 1973. The enlarged Community of the Nine is one of the world's leading economic units, with some 250 million inhabitants.

\section{COMMON POLICIES}

Common policies and common approaches have been progressively introduced-but not without difficulty and extremely diverse legislation covering all sectors of the Community's economic and social life. In 1976 the process of building a united Europe is still unfinished. Certain common policies are incomplete; in some fields a common policy does not even exist. Often Community responsibility in an area of policy coexists with prerogatives which Member States have retained. It should be realized, however, that not all the objectives of the European Treaties can necessarily be achieved by identical methods. In some fields they can be achieved by Community legislation alone; in others, Community activity has to be limited to progressively harmonizing national legislation; in others again, Community policy complements national policy.

Examples of the first category-Community legislation alone-are:

- The Common Customs Tariff (CCT) on trade with third countries. Customs duties between Member States have been abolished since 30 June 1968 (1 July 1977 for the three new Member States).

Even so, some barriers to the free movement of goods within the EEC do still exist, mainly because of indirect taxation (particularly value added tax (VAT)) that is difficult to harmonize, and because of differences in administrative methods.

- The free movement of workers: EEC citizens going to work in other 
member countries no longer need a work permit.

- The common agricultural policy (CAP) : despite its critics, it has proved to be an effective instrument for stabilizing markets and guaranteeing food supplies.

In the second category, good examples of progressive harmonization of legislation and policy coordination are:

- Environment and consumer protection, where the aim is Community-wide anti-pollution norms, and quality and hygiene standards, for food and other products, accepted throughout the area.

- Research, technology and industry, where the Nine are trying to coordinate their national policies and implement projects of common interest.

In the third category, Community policy as a complement to national policy, mention can be made of:

- Development policy: besides the instruments described above, Member States have their own national policies to the Third World, especially food aid and financial aid. - Social policy, where the Nine are not trying to introduce a single policy to deal with all the Community's social problems in a uniform way, nor transfer responsibility and operational power carried out at national level, but Community action aims at making each country's policy as complete as possible.

- Regional policy, where the Community sets long-term guidelines and the European Regional Development Fund finances projects which fall within these guidelines.
The preamble to the Treaty of Rome lays down guidelines for Community action, in particular: - '...to ensure the economic and social progress of their countries by common action to eliminate the barriers which divide Europe,

- '...constant improvement of the living and working conditions of their peoples,'

- '...guarantee steady

expansion, balanced trade and fair competition,

- ". to strengthen the unity of their economies and to ensure their harmonious development by reducing the differences existing between the various regions and the backwardness of the less-favoured regions,

- ' to confirm the solidarity

which binds Europe and the overseas countries...,

\section{EUROPEAN COMMUNITY INSTITUTIONS}

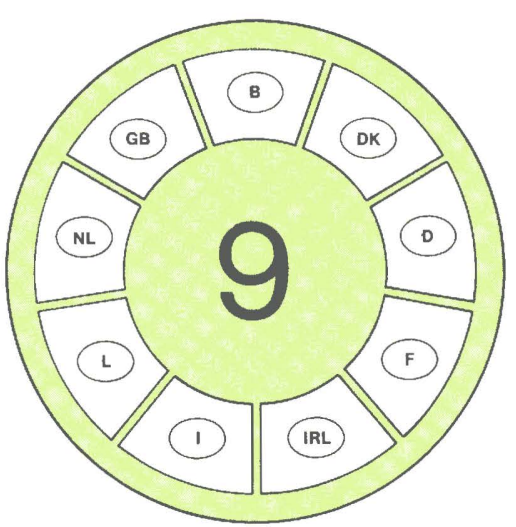

THE COUNCIL OF MINISTERS

Its function is to decide on. proposals prepared by the Commission. It is made up of one or more ministers from each

Member State and usually meets in Brussels. Exactly who attends depends on the subjects dealt with: when major political issues are discussed the Foreign Ministers take part; for subjects like agriculture, finance, environment or development relevant ministers take part. The Council of Ministers has a permanent secretariat in Brussels in a building next door to the European Commission. For the day-to-day running of Community affairs, each member government has a Permanent Representative in Brussels. The Permanent Representatives meet weekly to prepare for meetings of the Council, and take decisions that do not require agreement at political level. 

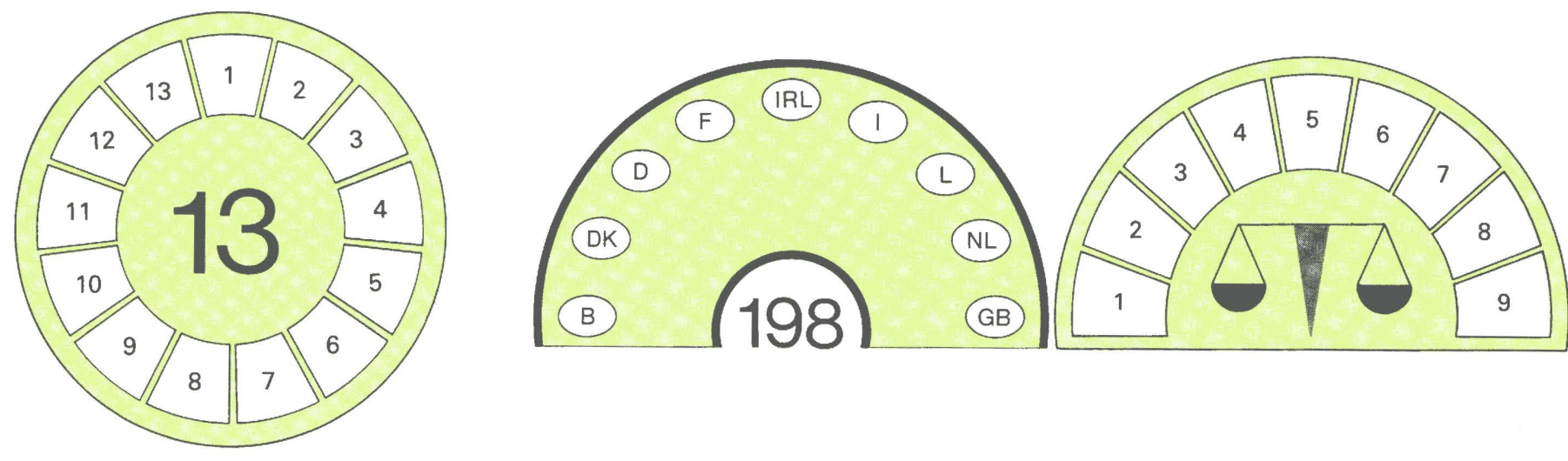

\section{THE EUROPEAN COMMISSION}

The main function of the Commission of the European Communities is to initiate policy, under the guidelines set out in the Treaties, or by the Council. It is also the 'guardian of the Treaties', and the executive arm of the Community. In case of infringements by Member States it can take them to the Court of Justice. It manages the Community funds: European Agricultural Guidance and Guarantee Funds (EAGGF), the European Development Fund $(E D F)$, the European Social Fund and the European Regional Development Fund. It has thirteen members (two German, one Belgian, two British, one Danish, two French, one Irish, two Italian, one Luxembourgeois, and one Dutch) appointed by the governments but bound to act independently of both governments and the Council. The Commission's offices are principally located in Brussels and Luxembourg. It is organized in 20 Directorates-General, including external relations, economic and financial affairs, agriculture, development, etc. plus specialized services, such as the Statistical Office.

\section{THE EUROPEAN PARLIAMENT}

The principal formal function of the Parliament is to give its own opinions on proposals from the Commission. It is currently made up of 198 members who are delegated by the national parliaments of each Member State. It holds about 14 plenary sessions each year, mainly in Strasbourg, but occasionally at Luxembourg where its permanent secretariat is located. Its specialized parliamentary committees hold some 300 meetings a year. In 1978 the European Parliament is to be elected for the first time by direct universal suffrage.

\section{THE COURT OF JUSTICE}

The Court of Justice consists of nine judges, appointed jointly by all the governments. It is assisted by four advocates-general, who give an independent view on cases. It sits in Luxembourg. It is the final authority on all legal matters falling within the domain of the Treaties. It rules on cases between Member States and the Commission. Its decisions are binding on Member States, Community Institutions and all individuals. National courts can appeal to it for rulings on how to interpret Community law.

\section{OTHER INSTITUTIONS}

The European Investment Bank (EIB) is an independent public body based in Luxembourg. It encourages the balanced interior development of the Community by granting long-term loans and bank guarantees. It is also empowered to grant loans within the framework of association agreements with Greece and Turkey, agreements with Algeria, Morocco, Tunisia, Egypt, Syria, Jordan, Lebanon and Israel, and within the framework of the Lomé Convention. There are also over 70 specialized committees contributing to the work of the Community. The most important are the Economic and Social Committee, the Coal and Steel Consultative Committee, and the Monetary Committee. 
THE MAJOR DATES

OF THE EUROPEAN COMMUNITY

18. 4.1951 Signing of the ECSC Treaty in Paris by six European countries: Belgium, France,

Luxembourg, Italy, the Federal Republic of Germany and the Netherlands. The common market for coal, iron and scrap iron was formed on 10.2.1952, and that of steel on 1.5.1953.

25. 3.1957 Signature of the Treaties of Rome by the same six countries setting up the European Economic Community $(E E C)$ and Euratom which came into operation on 1.1.1958.

1. 7.1967 The institutions of the three Communities create a single Council of Ministers and a single executive : the Commission of the European Communities.

1 and 2.12.1969 'Summit' of The Hague opening to Great Britain the possibility of accession to the Community.

21. 4.1970 The budget of the European Community acquires its own resources, replacing contributions from Member States.

22. 1.1972 Signature in Brussels of the treaties enlarging the Community to Nine, with Denmark, Ireland and United Kingdom.

1. 1.1973 The enlargement takes effect.

12. 6.1975 Greece officially requests accession to the Community, a request approved in February 1976 by the Council of Ministers.

20. 9.1976 Signature in Brussels by the Nine of the agreement on direct elections to the European Parliament. 


\section{HOW THE INSTITUTIONS OF THE EUROPEAN COMMUNITY WORK}

(simplified diagram)

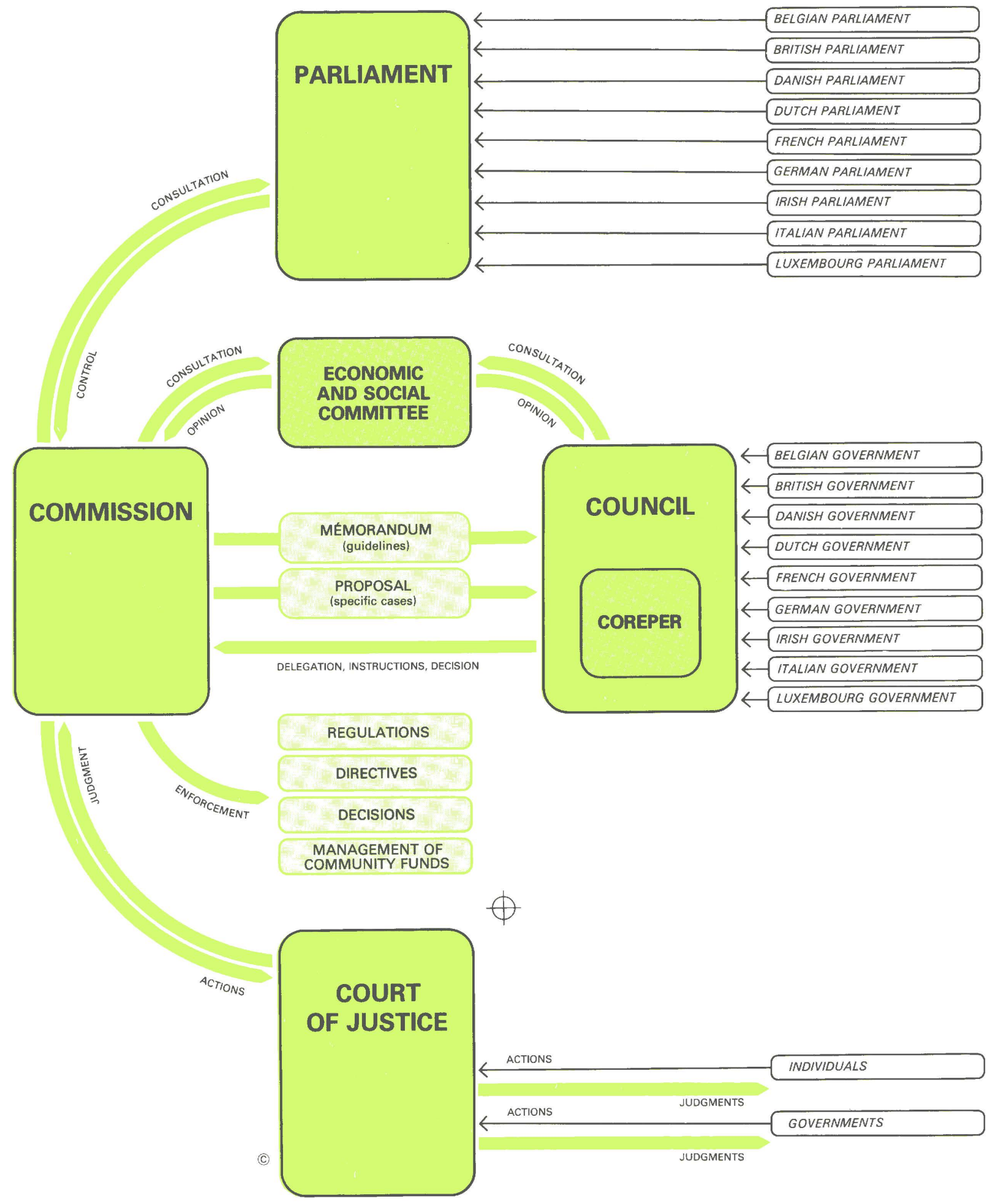


Spokeman's Group and Directorate-General for Information Rue de la Loi 200, 1049 Brussels, Belgium

Tel: $7350040 / 7358040$

Press and Information Offices
THIRD COUNTRIES

\section{BELGIUM}

Rue Archimède 73, 1049 Bruxelles Archimedestraat 73, 1049 Brussel Tel. $7350040 / 7358040$

\section{DENMARK}

Gammel Torv 4

Postbox 144

1004 Kobenhavn K

Tel. $144140 / 145532$

FEDERAL REPUBLIC OF GERMANY

Zitelmannstraße 22

5300 Bonn

Tél 238041

Berlin (branch of Bonn Office)

Kurfürstendamm 102

100 Berlin 31

Tel. 8864028

FRANCE

61 , rue des Belles-Feuilles

75782 Paris Cedex 16

Tel. 5535326

ITALY

Via Poli 29

00187 Roma

Tel. 689722

LUXEMBOURG

Bâtiment Jean Monnet

Rue Alcide de Gasperi

Luxembourg-Kirchberg

Tel. 43011

IRELAND

29 Merrion Square

Dublin 2

Tel. 760353

NETHERLANDS

Lange Voorhout 29

Den Haag

Tel. 469326

UNITED KINGDOM

20 Kensington Palace Gardens

London W8400

Tel. 7278090

Edinburgh (branch of

London Office)

7 Alva Street

Edinburgh EH $24 \mathrm{PH}$

Tel. 2252058

Cardiff (Branch of

London Office)

4 Cathedral Road

PO Box 15

Cardiff CF1 1WF

Tel 371631

\section{CANADA}

Association House (Suite 1110)

350 Sparks Street

Ottawa Ont. KIR 7S8

Tel. 2386464

CHILE

Avenida Ricardo Lyon 1177

Santiago 9

Postal address: Casilla 10093

Tel. 250555

UNITED STATES

2100 M Street, NW

Suite 707

Tel. (202) 8728350

New York (Branch of Washington Office)

1 Dag Hammarskiöld Plaza

245 East 47th Street

New York NY 10017

Tel. (212) 3713804

\section{GREECE}

2. Vassilissis Sofias

T.K. 1602

Athina 134

Tel. 743982/743983/743984

JAPAN

Kowa 25 Building

8-7 Sanbancho

Chiyoda-Ku

Tokyo 102

Tel. 2390441

SWITZERLAND

Case postale 195

37-39, rue de Vermont

12011 Genève 20

Tel. 349750

TURKEY

13, Bogaz Sokak

Kavaklidere

Ankara

Tel. 276145/276146
Washington DC 20037 


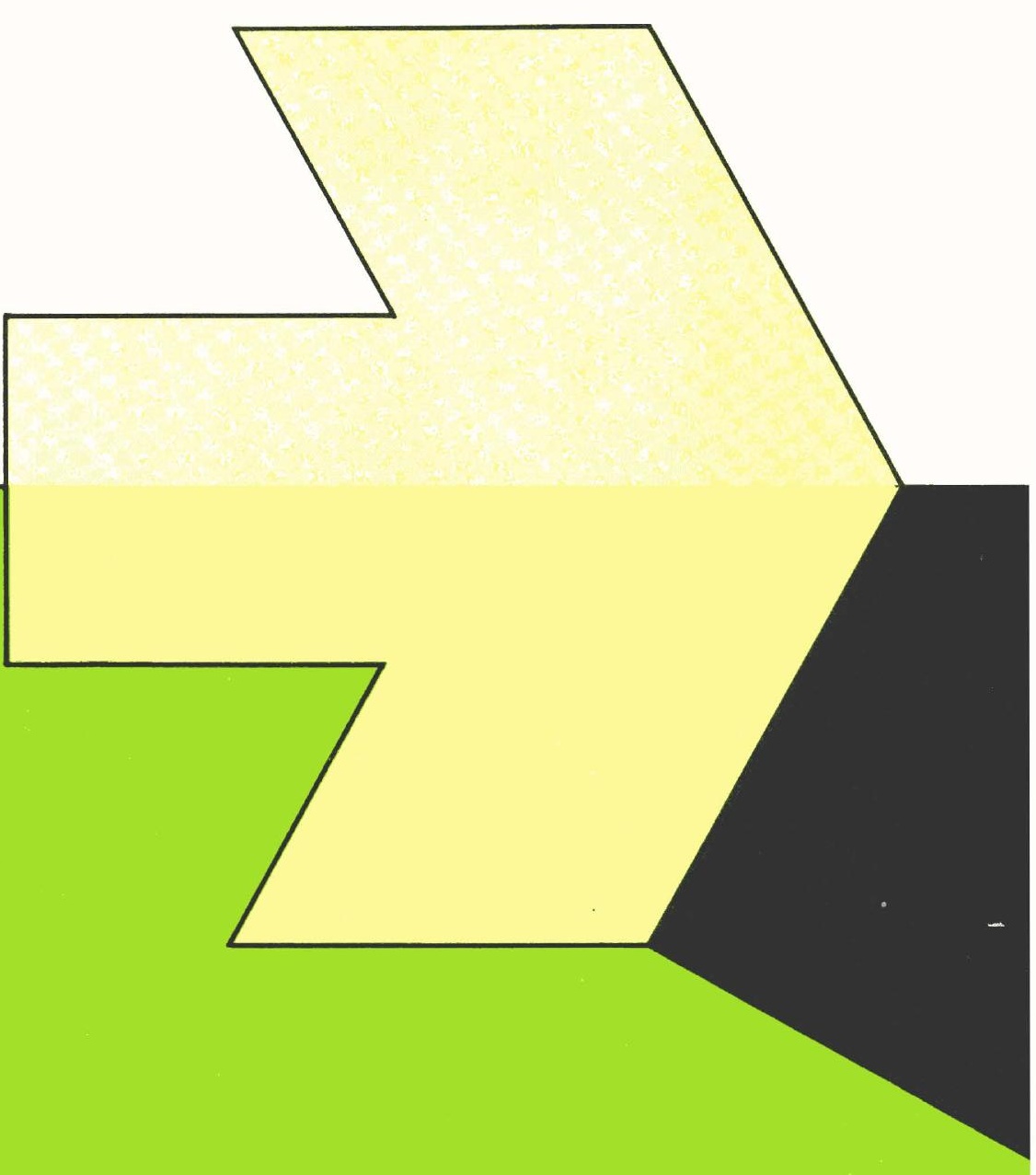

